Prepared in cooperation with the Bureau of Reclamation, U.S. Department of the Interior

\title{
Cluster Analysis of Water-Quality Data for Lake Sakakawea, Audubon Lake, and McClusky Canal, Central North Dakota, 1990-2003
}

Scientific Investigations Report 2006-5202 



\section{Cluster Analysis of Water-Quality Data for Lake Sakakawea, Audubon Lake, and McClusky Canal, Central North Dakota, 1990-2003}

By Karen R. Ryberg

Prepared in cooperation with the Bureau of Reclamation, U.S. Department of the Interior

Scientific Investigations Report 2006-5202 


\section{U.S. Department of the Interior DIRK KEMPTHORNE, Secretary \\ U.S. Geological Survey \\ P. Patrick Leahy, Acting Director}

\section{U.S. Geological Survey, Reston, Virginia: 2006}

For product and ordering information:

World Wide Web: http://www.usgs.gov/pubprod

Telephone: 1-888-ASK-USGS

For more information on the USGS--the Federal source for science about the Earth, its natural and living resources, natural hazards, and the environment:

World Wide Web: http://www.usgs.gov

Telephone: 1-888-ASK-USGS

Any use of trade, product, or firm names is for descriptive purposes only and does not imply endorsement by the U.S. Government.

Although this report is in the public domain, permission must be secured from the individual copyright owners to reproduce any copyrighted materials contained within this report.

Suggested citation:

Ryberg, K.R., 2006, Cluster Analysis of Water-Quality Data for Lake Sakakawea, Audubon Lake, and McClusky Canal, Central North Dakota, 1990-2003: U.S. Geological Survey Scientific Investigations Report 2006-5202, 38 p. 


\section{Contents}

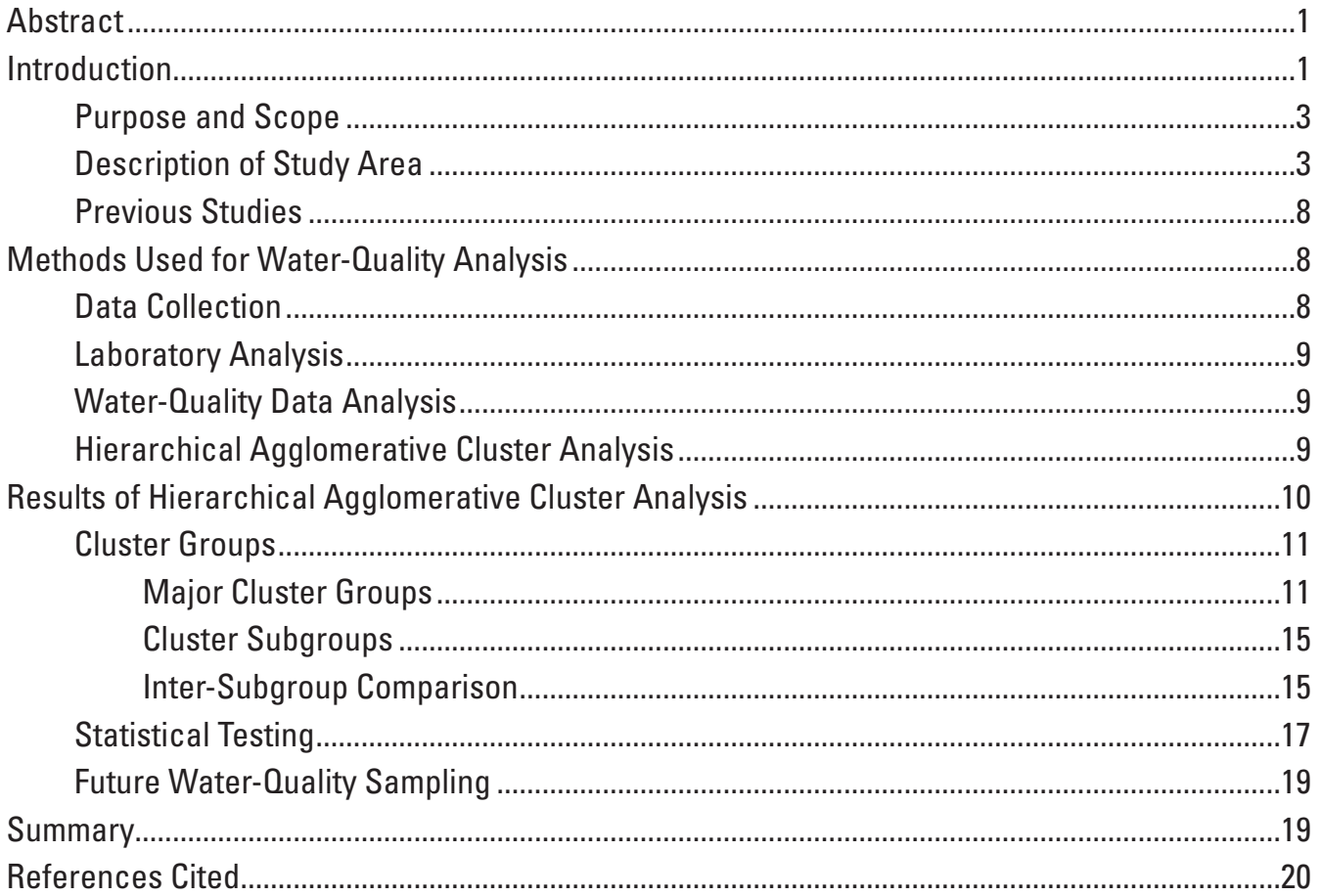

\section{Figures}

1. Map showing location of Lake Sakakawea, Audubon Lake, and McClusky Canal in central North Dakota........................................................................................................

2. Map showing location of sampling sites in the study area and sections of the McClusky Canal

3. Water-surface elevations of Lake Sakakawea and Audubon Lake at Snake Creek Pumping Plant, 1990-2005 ...........................................................................................

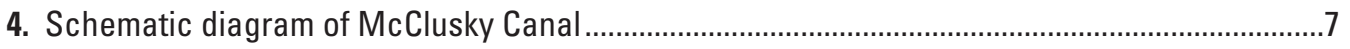

5. Dendrogram from hierarchical agglomerative cluster analysis of 409 surface-water samples collected from Lake Sakakawea, Audubon Lake, and McClusky Canal, 1990-2003

6. Dendrogram showing groups and subgroups of surface-water samples examined in this study

7. Graph showing total dissolved-solids concentrations in samples from water-quality sampling sites located in section WS 2, 1990-2003. 


\section{Tables}

1. Water-quality sampling sites on Lake Sakakawea, Audubon Lake, and McClusky Canal, central North Dakota.

2. Water-quality physical properties and constituents examined in this study, Lake Sakakawea, Audubon Lake, and McClusky Canal, central North Dakota, 1990-2003

3. Summary statistics for uncensored water-quality physical properties and constituents at sampling sites on Lake Sakakawea, Audubon Lake, and McClusky Canal, central North Dakota, 1990-2003.

4. Summary statistics for censored water-quality constituents at sampling sites on Lake Sakakawea, Audubon Lake, and McClusky Canal, central North Dakota, 1990-2003

5. Water-quality physical properties and constituents used in hierarchical agglomerative cluster analysis of water-quality samples from Lake Sakakawea, Audubon Lake, and McClusky Canal, central North Dakota, 1990-2003

6. Water-quality sampling sites on Lake Sakakawea, Audubon Lake, and McClusky Canal, central North Dakota, and percentage of samples that fall into cluster groups $\mathrm{A}, \mathrm{B}$, and $\mathrm{C}$

7. Total dissolved-solids concentrations in samples from water-quality sampling sites located in section WS 2 of McClusky Canal, central North Dakota, 1990- 2003

8. Water-quality sampling sites on Lake Sakakawea, Audubon Lake, and

McClusky Canal, central North Dakota, and percentage of samples that fall into cluster subgroups 1-6

9. Mean concentrations for uncensored constituents in subgroups determined from hierarchical agglomerative cluster analysis, Lake Sakakawea, Audubon Lake, and McClusky Canal, central North Dakota, 1990-2003

10. Median concentrations for censored constituents in subgroups determined from hierarchical agglomerative cluster analysis, Lake Sakakawea, Audubon Lake, and McClusky Canal, central North Dakota, 1990-2003

11. P-values for Kruskal-Wallis test of significant difference between cluster groups and subgroups for water-quality samples collected from Lake Sakakawea, Audubon Lake, and McClusky Canal, central North Dakota, 1990-2003.

12. $P$-values for test of significant difference between cluster subgroups in group $A$ for water-quality samples collected from Lake Sakakawea, Audubon Lake, and McClusky Canal, central North Dakota, 1990-2003. 


\section{Conversion Factors, Abbreviations, and Datum}

\begin{tabular}{lcl}
\hline \multicolumn{1}{c}{ Multiply } & \multicolumn{1}{c}{ By } & \multicolumn{1}{c}{ To obtain } \\
\hline foot $(\mathrm{ft})$ & Length & \\
mile $(\mathrm{mi})$ & 0.3048 & meter $(\mathrm{m})$ \\
\hline & 1.609 & kilometer $(\mathrm{km})$ \\
\hline cubic foot per second $\left(\mathrm{ft}^{3} / \mathrm{s}\right)$ & Flow rate & \\
\hline
\end{tabular}

Temperature in degrees Celsius $\left({ }^{\circ} \mathrm{C}\right)$ may be converted to degrees Fahrenheit $\left({ }^{\circ} \mathrm{F}\right)$ as follows:

$$
{ }^{\circ} \mathrm{F}=\left(1.8 \times{ }^{\circ} \mathrm{C}\right)+32 .
$$

Temperature in degrees Fahrenheit $\left({ }^{\circ} \mathrm{F}\right)$ may be converted to degrees Celsius $\left({ }^{\circ} \mathrm{C}\right)$ as follows:

$$
{ }^{\circ} \mathrm{C}=\left({ }^{\circ} \mathrm{F}-32\right) / 1.8 \text {. }
$$

Vertical coordinate information is referenced to the National Geodetic Vertical Datum of 1929 (NGVD 29).

Horizontal coordinate information is referenced to the North American Datum of 1927 (NAD 27).

Elevation, as used in this report, refers to distance above the vertical datum.

Specific conductance is given in microsiemens per centimeter at 25 degrees Celsius $\left(\mu \mathrm{S} / \mathrm{cm}\right.$ at $\left.25^{\circ} \mathrm{C}\right)$.

Concentrations of chemical constituents in water are given in milligrams per liter (mg/L). 
This page intentionally blank. 


\title{
Cluster Analysis of Water-Quality Data for Lake Sakakawea, Audubon Lake, and McClusky Canal, Central North Dakota, 1990-2003
}

\author{
By Karen R. Ryberg
}

\section{Abstract}

As a result of the Dakota Water Resources Act of 2000, the Bureau of Reclamation, U.S. Department of the Interior, identified eight water-supply alternatives (including a noaction alternative) to meet future water needs in portions of the Red River of the North (Red River) Basin. Of those alternatives, four include the interbasin transfer of water from the Missouri River Basin to the Red River Basin. Three of the interbasin transfer alternatives would use the McClusky Canal, located in central North Dakota, to transport the water. Therefore, the water quality of the McClusky Canal and the sources of its water, Lake Sakakawea and Audubon Lake, is of interest to water-quality stakeholders.

The Bureau of Reclamation collected water-quality samples at 23 sites on Lake Sakakawea, Audubon Lake, and the McClusky Canal system from 1990 through 2003. Physical properties and water-quality constituents from these samples were summarized and analyzed by the U.S. Geological Survey using hierarchical agglomerative cluster analysis (HACA). HACA separated the samples into related clusters, or groups. These groups were examined for statistical significance and relation to structure of the McClusky Canal system.

Statistically, the sample groupings found using HACA were significantly different from each other and appear to result from spatial and temporal water-quality differences corresponding with different sections of the canal and different operational conditions. Future operational changes of the canal system may justify additional water-quality sampling to characterize possible water-quality changes.

\section{Introduction}

The Dakota Water Resources Act, passed by the U.S. Congress on December 15, 2000, authorized the Secretary of the Interior to conduct a comprehensive study of the future water needs of the Red River Basin in North Dakota and of possible options to meet those water needs (U.S. Congress, 2000). Water needs are expected to increase in the basin due to population growth and the possibility of future drought.

As part of the comprehensive water needs study, the Bureau of Reclamation identified eight water-supply alternatives for the Red River Valley Water Supply Project (RRVWSP). Of those alternatives, four include the interbasin transfer of water from the Missouri River Basin to the Red River Basin. Three of the four interbasin transfer alternatives transfer water from the Missouri River Basin to the Red River Basin through Audubon Lake, the McClusky Canal, and a pipeline (U.S. Department of Interior, Bureau of Reclamation, 2005). The three options utilizing Audubon Lake and McClusky Canal (fig. 1) are identified as "GDU Import" in Bureau of Reclamation reports because they import water to the Red River Basin utilizing the Garrison Diversion Unit (GDU).

The GDU was created by the U.S. Congress on August 5, 1965. The GDU includes Snake Creek Pumping Plant on Lake Sakakawea, Audubon Lake, and the McClusky Canal. The original intent of the GDU was to provide water for agricultural irrigation in North Dakota. Congress passed the Garrison Diversion Unit Reformulation Act in 1986 changing the primary focus of the GDU from irrigation to municipal water supply. In 2000, Congress further amended the Garrison Diversion Unit Reformulation Act of 1986 with the Dakota Water Resources Act (DWRA). Section 8 of DWRA directed the Secretary of the Interior to prepare a report on the Red River Valley Needs and Options and an Environmental Impact Statement.

During the period of record, there have been no flows through the GDU into the Red River Basin as part of the RRVWSP. Also, there is no connection between the McClusky Canal and the New Rockford Canal (another part of the GDU). The possibility of the interbasin transfer of water from a basin that drains into the Gulf of Mexico (the Missouri River) to a basin that drains into Hudson Bay in Canada (the Red River) has caused concern among water-quality stakeholders in the Red River Basin in the United States and Canada. 


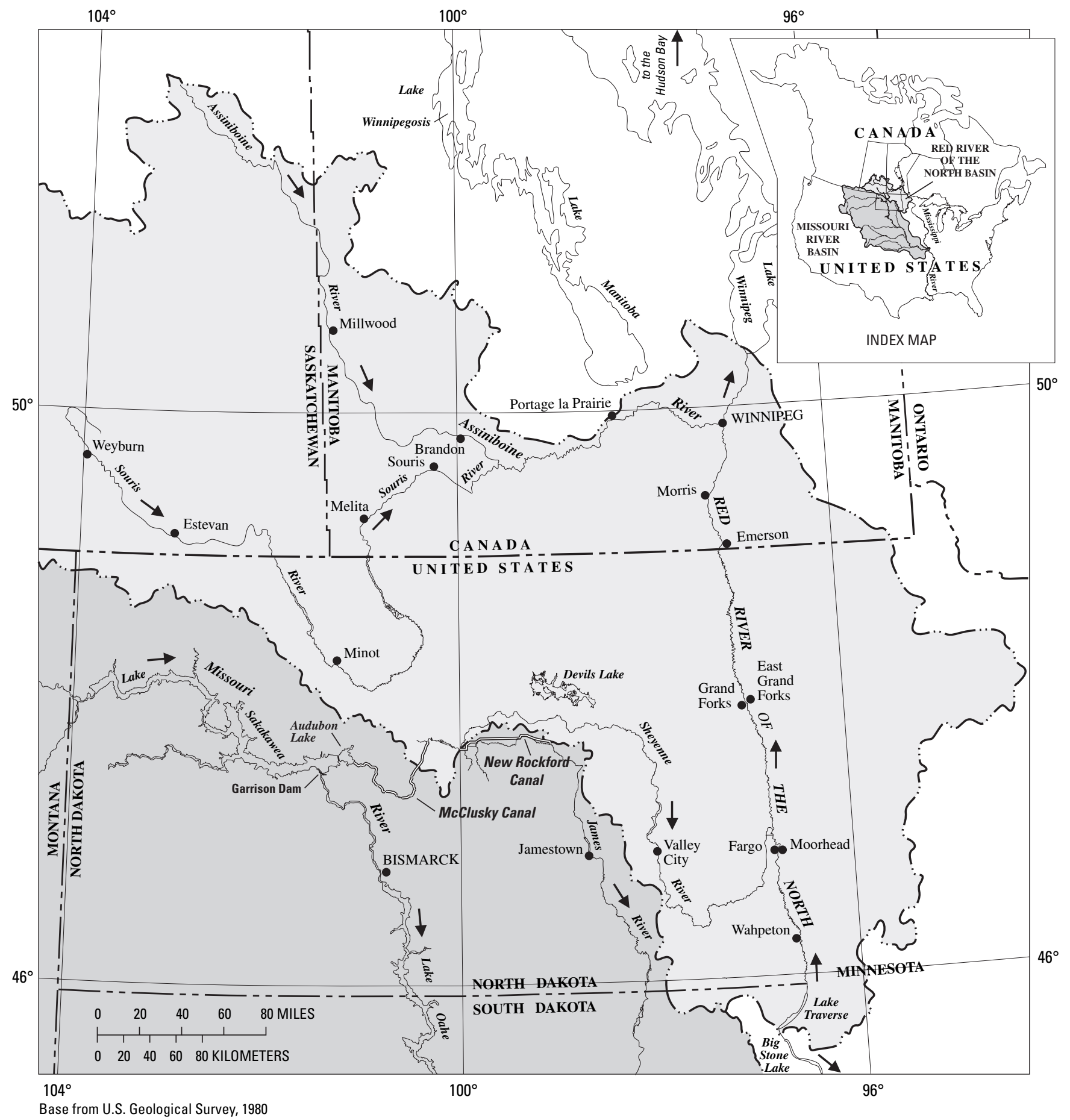

EXPLANATION

Red River of the North Basin

Missouri River Basin

- $\cdots-$ Basin boundary

$\rightarrow \quad$ Direction of water flow

Figure 1. Location of Lake Sakakawea, Audubon Lake, and McClusky Canal in central North Dakota. 
For the RRVWSP, the Bureau of Reclamation needs to have an understanding of the water quality of the potential source water for this project and an understanding of how the water quality is affected by present and potential future operations of the system. The U.S. Geological Survey, in cooperation with the Bureau of Reclamation, performed a study to understand the water quality of the potential source water in Lake Sakakawea, Audubon Lake, and McClusky Canal for the RRVWSP.

\section{Purpose and Scope}

The purpose of this report is to summarize water-quality data collected by the Bureau of Reclamation from 23 sampling sites on Lake Sakakawea, Audubon Lake, and McClusky Canal from May 1990 through September 2003 and to present the results of hierarchical agglomerative cluster analysis (HACA). Locations of these sites are shown in figure 2, and site descriptions, site locations, and period of record at each site are provided in table 1 . The report summarizes the waterquality data and describes the HACA method and the resulting clustering of 409 samples in terms of the physical properties and major ions found in the water-quality samples. The clustering is related to temporal and spatial differences in water quality in Lake Sakakawea, Audubon Lake, and McClusky Canal.

The information in this report can be used by the Bureau of Reclamation to determine future water-quality sampling needs. The methods used in this report can be applied nationwide to help describe water-quality data in terms of temporal and spatial differences.

\section{Description of Study Area}

The study area includes Snake Creek Pumping Plant on Lake Sakakawea, Audubon Lake, and McClusky Canal, which are all part of the GDU (fig. 2). The water level of Lake Sakakawea, the reservoir created by Garrison Dam (earthwork was completed in 1954) on the Missouri River, is controlled by U.S. Army Corps of Engineers releases from the dam. The water level of Lake Sakakawea may fluctuate in response to many factors including downstream water needs, Rocky Mountain snowmelt, surface-water runoff, and flood-control needs.

Lake Sakakawea and Audubon Lake are separated by the U.S. Highway 83 causeway. The Snake Creek Pumping Plant, constructed from 1969 to 1976, pumps Missouri River water from Lake Sakakawea to Audubon Lake. Audubon Lake was filled in 1975 and acts as a holding reservoir for water before it is released into the McClusky Canal. Water in Audubon Lake is kept at an almost constant level. Audubon Lake had a mean water-surface elevation of $1,845.8 \mathrm{ft}$ during the period of this study. Each spring, the Snake Creek Pumping Plant is used to fill Audubon Lake to an elevation of 1,847.0 ft and to maintain the lake at that level through August. From Septem- ber through mid-November, the lake is lowered to an elevation of $1,845.0 \mathrm{ft}$ by releasing water down the McClusky Canal, down Painted Woods Creek to the Missouri River, and through a conduit in the Snake Creek embankment that returns water to Lake Sakakawea. The fall drawdown helps maintain freshness in Audubon Lake and protects constructed island stabilization measures from ice damage (R. Nelson, Bureau of Reclamation, written commun., 2006). The variation in the elevations of Lake Sakakawea and Audubon Lake from 1990 through 2005 is shown in figure 3.

The McClusky Canal (figs. 1 and 2) is a 73.6-mi-long canal originally designed as the principal GDU supply feature that would transport Missouri River water to central and eastern North Dakota for project purposes, including water supply for communities in the Red River Valley. The canal crosses the divide between the Gulf of Mexico drainage basin and the Hudson Bay drainage basin near canal mile 59, where it is plugged to prevent flow of untreated Missouri River water into the Hudson Bay Basin.

The first $31 \mathrm{mi}$ of the canal were filled with water from Audubon Lake in 1979. The remaining $42.6 \mathrm{mi}$ of the canal filled naturally with surface-water runoff and ground-water contributions. Water in the canal consists of five sections separated by radial gates or plugs (fig. 4). These sections are designated by "WS," for water surface, and a number. Section WS 1 from the canal headworks, sampling site 3B-2, to the radial gate at canal mile 20 , site $3 \mathrm{E}-1$, has an operational target elevation of $1,843.0$ to $1,845.5 \mathrm{ft}$. Section WS 2, also known as the Chain of Lakes, includes that part of the canal from site $3 \mathrm{E}-2$ to the plug at canal mile 52 , site $3 \mathrm{H}-1$. The section has a target elevation of $1,839.0$ to $1,840.5 \mathrm{ft}$ and is the section from which water is released down Painted Woods Creek. Section WS 2 is a combination of former WS 2 and former WS 3, which were connected as part of the canal freshening program. For the time period of this study, there was no WS 3. Section WS 4, from site $3 \mathrm{H}-2$ to the radial gate at site $3 \mathrm{I}-1$, has a target elevation of $1,839.0$ to $1,840.5 \mathrm{ft}$. Section WS 5, also known as Hoffer Lake, from site 3I-2 through site $3 \mathrm{~K}$, has a target elevation of $1,839.0$ to $1,840.5 \mathrm{ft}$. Section WS 6, also known as Skunk Lake, which includes site 3J, has a target elevation of $1,831.0$ to $1,837.0 \mathrm{ft}$ (M. Marohl, Bureau of Reclamation, oral commun., 2006, and unpublished data on file with the Bureau of Reclamation).

The Audubon Lake-McClusky Canal freshening program began in 1984 when the headworks at Audubon Lake were opened. Since that time, water has continued to flow through the canal to New Johns Lake (see section WS 2 in figure 2). Releases from New Johns Lake to Painted Woods Creek also began in 1984. Releases at the headworks varied from 0 to $100 \mathrm{ft}^{3} / \mathrm{s}$ from 1984 through 1999 and from 0 to $40 \mathrm{ft}^{3} / \mathrm{s}$ from 2000 through 2003. Releases down Painted Woods Creek varied from 0 to $40 \mathrm{ft}^{3} / \mathrm{s}$ from 1984 through 1999 and from 0 to $20 \mathrm{ft}^{3} / \mathrm{s}$ from 2000 through 2003 (M. Marohl., Bureau of Reclamation, oral commun., 2006, and unpublished data on file with the Bureau of Reclamation). 


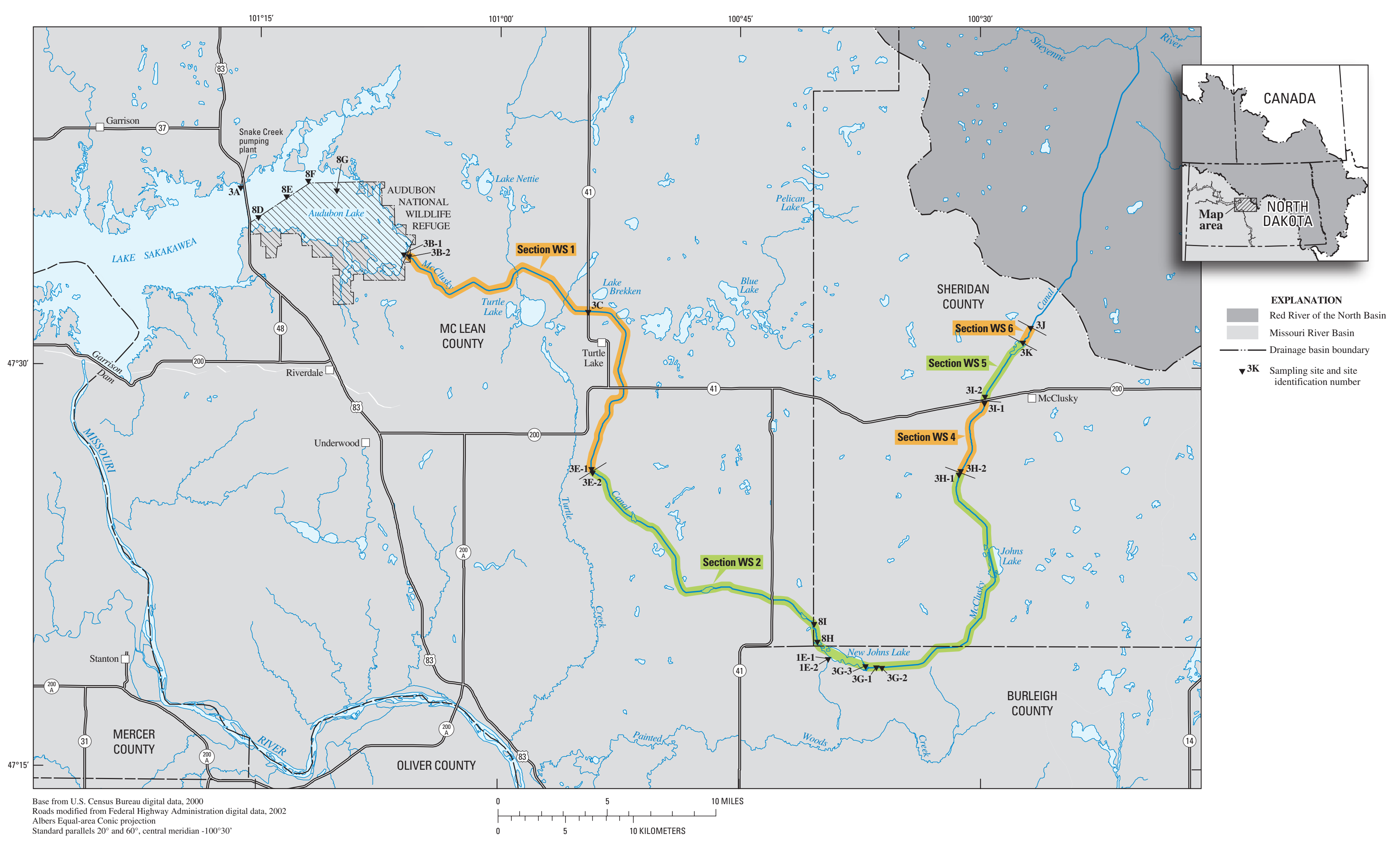

Figure 2. Location of sampling sites in the study area and sections of the McClusky Canal. Section WS 2 is a combination of former WS 2 and former WS 3 . 
Table 1. Water-quality sampling sites on Lake Sakakawea, Audubon Lake, and McClusky Canal, central North Dakota.

[Sites are listed in downstream order; map numbers are the Bureau of Reclamation site identification numbers; ft, feet]

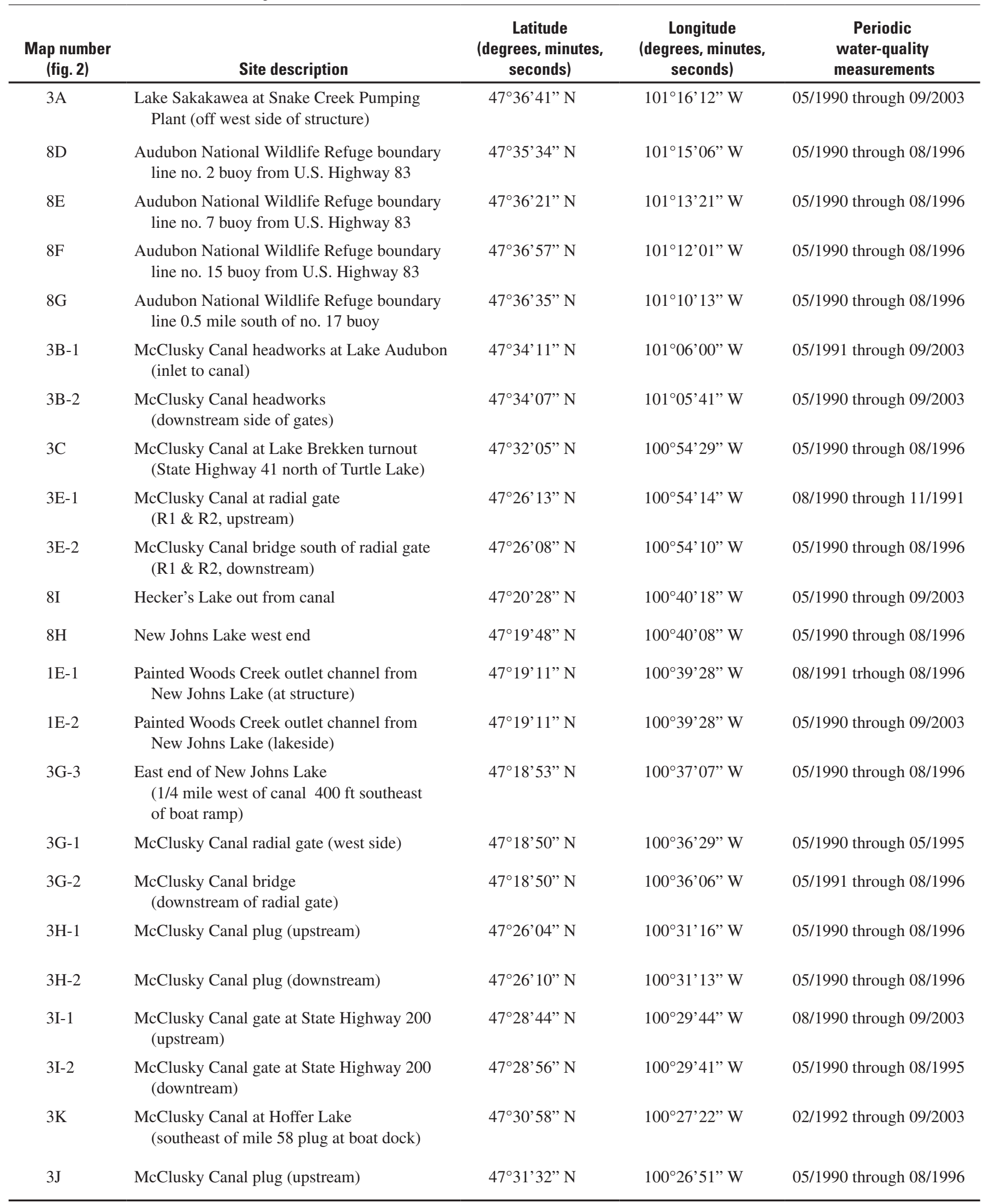




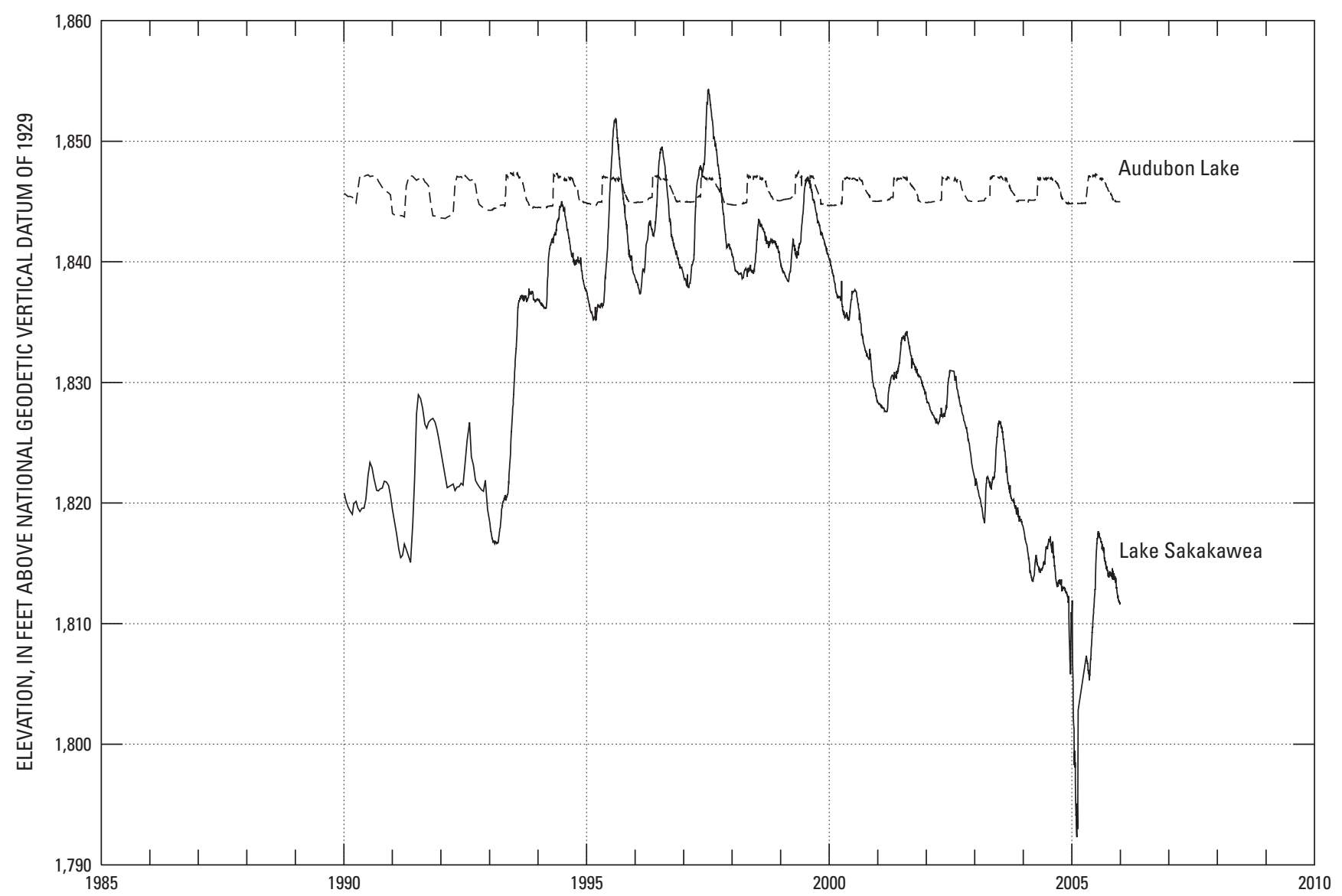

Figure 3. Water-surface elevations of Lake Sakakawea and Audubon Lake at Snake Creek Pumping Plant, 1990-2005.

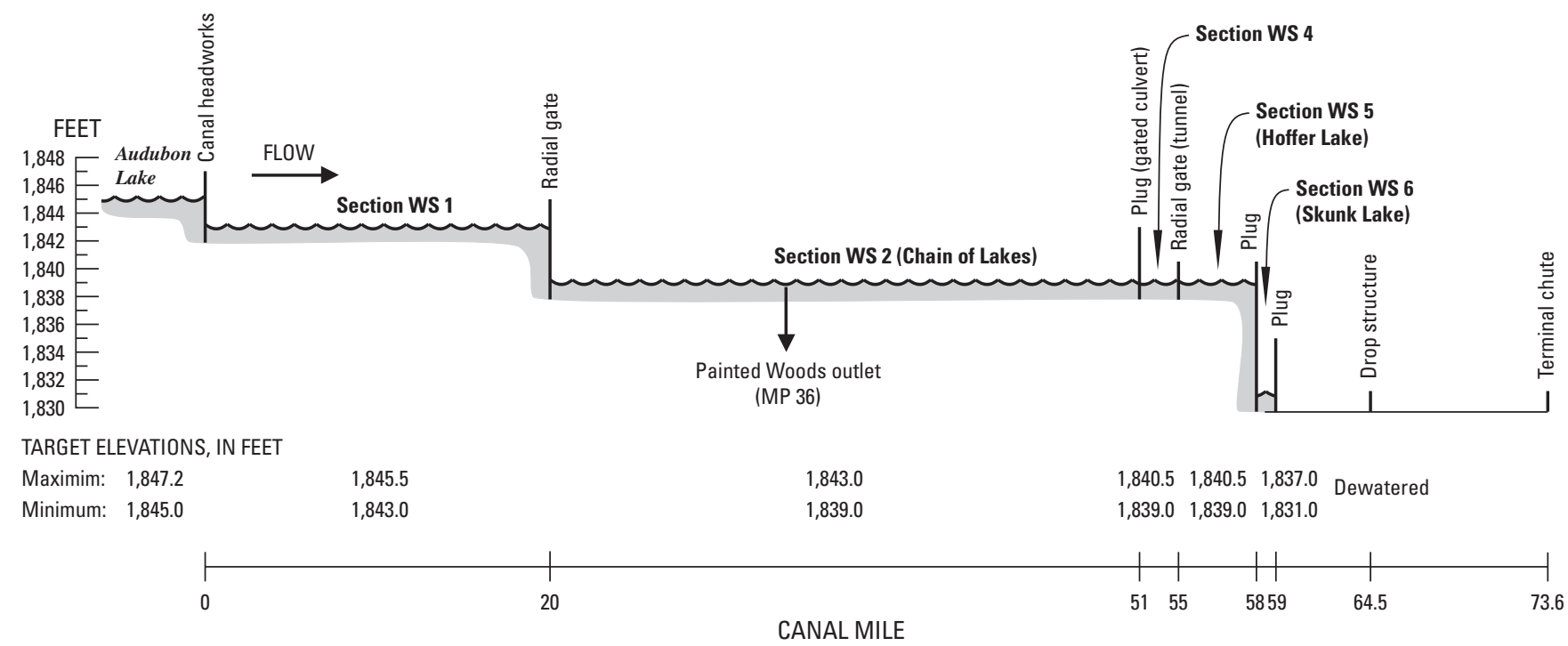

Figure 4. Schematic diagram of McClusky Canal. Section WS 2 is a combination of former WS 2 and former WS 3 (M. Marohl, Bureau of Reclamation, oral commun., 2006). 
Downstream from New Johns Lake, there is no outlet and thus essentially no flow in the canal. To maintain target elevations, water is pumped in reverse from sections WS 4, WS 5, and WS 6 to section WS 2 (M. Marohl, Bureau of Reclamation, oral commun., 2006, and unpublished data on file with the Bureau of Reclamation).

\section{Previous Studies}

Previous studies of water quality related to the GDU have focused on the potential water-quality impact on the James River (Briel, 1988; Sando and others, 1990) and the Sheyenne/Red River system (Guenthner, 1991, 1993) if streamflows were augmented by water from the GDU. Studies also have examined the effects of GDU irrigation on ground water (Goolsby and others, 1989; Berkas and Komor, 1996) and the James River (Briel, 1989).

\section{Methods Used for Water-Quality Analysis}

This section describes how water-quality samples were collected and analyzed and how the data were summarized and interpreted for this study.

\section{Data Collection}

The Bureau of Reclamation records the water-surface elevation of Lake Sakakawea and Audubon Lake at the Snake Creek Pumping Plant using float-wells which are accurate to $0.01 \mathrm{ft}$. Those data are plotted in figure 3 . Measurement frequency was generally four to five measurements per week (G. Hiemenz, Bureau of Reclamation, written commun., 2006).

From May 1990 through September 2003, the Bureau of Reclamation collected water-quality samples from 23 sampling sites in the study area (table 1). The lake water-quality samples were depth integrated using a weighted bottle lowered and raised in and out of the lake to obtain a sample representative of the whole water column (D. Hartman, Bureau of Reclamation, oral commun., 2006). Methods for sites on the McClusky Canal varied. If obtained from a bridge or through a hole in the ice, samples were depth integrated using a weighted bottle. Some samples, such as those at plugs, were dip samples (D. Hartman, Bureau of Reclamation, oral commun., 2006). Water-quality physical properties and constituents examined in this study are listed in table 2.

Table 2. Water-quality physical properties and constituents examined in this study, Lake Sakakawea, Audubon Lake, and McClusky Canal, central North Dakota, 1990-2003.

\begin{tabular}{ll}
\hline \multicolumn{1}{c}{ Constituent } & \multicolumn{1}{c}{ Unit of measurement } \\
\hline Specific conductance, field & Physical properties \\
pH, field & Standard units \\
Alkalinity & Milligrams per liter as calcium carbonate \\
\hline & Major ions and dissolved solids \\
\hline Calcium, dissolved & Milligrams per liter \\
Magnesium, dissolved & Milligrams per liter \\
Sodium, dissolved & Milligrams per liter \\
Potassium, dissolved & Milligrams per liter \\
Sulfate, dissolved & Milligrams per liter \\
Chloride, dissolved & Milligrams per liter \\
Total dissolved solids & Milligrams per liter \\
\hline & Nutrients \\
\hline Nitrite, dissolved & Milligrams per liter as nitrogen \\
Nitrate, dissolved & Milligrams per liter as nitrogen \\
Ammonia, dissolved & Milligrams per liter as nitrogen \\
Phosphorus & Milligrams per liter as phosphate \\
\hline
\end{tabular}




\section{Laboratory Analysis}

All water-quality samples were analyzed by the Bureau of Reclamation Dakotas Area Office Water and Soil Laboratory in Bismarck, North Dakota. Laboratory methods used were those of the manufacturer of the analyzing equipment and are based on U.S. Environmental Protection Agency approved methods (D. Hartman, Bureau of Reclamation, oral commun., 2006).

\section{Water-Quality Data Analysis}

All water-quality data were reviewed using time-series plots and summary statistics. The total anion charge was 85110 percent of the total cation charge for all complete waterquality samples. Two samples were identified as potential outliers, a sample from site 3B-2 collected on May 18, 1999, and a sample from site 3H-2 collected on February 19, 1992. A duplicate sample also was collected at site 3B-2 on May 18, 1999, for quality-control purposes. The two site 3B-2 samples had similar values, the charge balance error for both samples was less than 10 percent, and no obvious errors were found. Therefore, the May 18, 1999, sample from site 3B-2 was included in the study. The sample from site $3 \mathrm{H}-2$ appeared to be an outlier in terms of major cations and was missing specific conductance and $\mathrm{pH}$ values, both of which were needed for the statistical analysis. Therefore, the February 19, 1992, sample from site $3 \mathrm{H}-2$ was not included in the study. Summary statistics for uncensored water-quality physical properties and constituents at each site are listed in table 3 (at back of report).

Nitrite, nitrate, and phosphorus concentrations were highly censored. Censored values are values that are known to be less than a certain laboratory reporting level, but for which the exact value is not known. Of the samples used in this study, 93 percent of nitrite concentrations were censored at $0.02 \mathrm{mg} / \mathrm{L}, 80$ percent of nitrate concentrations were censored at $0.10 \mathrm{mg} / \mathrm{L}, 51$ percent of phosphorus concentrations were censored at $0.01 \mathrm{mg} / \mathrm{L}$, and 8 percent of ammonia concentrations were censored at $0.02 \mathrm{mg} / \mathrm{L}$.

Summary statistics for the censored constituents are listed in table 4 (at back of report). To calculate the summary statistics for the censored constituents, Helsel's (2005) guidelines were followed. For constituents at sites with more than 80 percent censoring, the maximum concentration was reported, the minimum was reported as less than the censoring level, and the $95^{\text {th }}$ percentile was reported if the data had 95 percent censoring or less. For constituents at sites with 50-80 percent censoring, the maximum concentration was reported, the minimum was reported as less than the censoring level, and the percentiles were estimated using regression on order statistics (ROS). The ROS method used is the "robust form" described in Helsel (2005), which is best when applied to small data sets $(\mathrm{n}<30)$, as is the case in this study with most water-quality sampling sites having fewer than 30 samples. For constituents at sites with less than 50 percent censoring, the maximum concentration was reported, the minimum was reported as less than the censoring level, and the percentiles are Kaplan-Meier estimates. The Kaplan-Meier method is described in Helsel (2005) and is a nonparametric method for estimating summary statistics. If a particular site had no censored values for a constituent, the summary statistics reported are actual values, not estimates.

\section{Hierarchical Agglomerative Cluster Analysis}

To examine the water-quality data for spatial and temporal differences, hierarchical agglomerative cluster analysis (HACA) was used. Güler and others (2002) described hierarchical cluster analysis as "an efficient means to recognize groups of samples that have similar chemical and physical characteristics." Various types of cluster analysis have been used to view water-chemistry data for both surface water (Alther, 1979; Güler and others, 2002) and ground water (Troiano and others, 1994; Farnham and others, 2000).

For the HACA used in this report, a subset of the waterquality constituents listed in table 2 was used (table 5). Total dissolved solids was not used in the cluster analysis because the amount of dissolved solids present is correlated to total ions present, represented by the major ions in table 5, and specific conductance, and "the use of variables that have specific relationships can cause undesirable redundancies in cluster analysis" (Güler and others, 2002).

Only 8 percent of the ammonia concentrations were censored. Therefore, ammonia was used in the cluster analysis. Substitution methods for the censored ammonia concentrations were examined. A substitute concentration based on the estimated mean of the uncensored data (Sanford and others, 1993) and a Kaplan-Meier estimate of the mean of the entire data set resulted in a substitute concentration of 0.02 , equal to the censoring level, so the censored ammonia concentrations were treated as observed values for the cluster analysis. The highly censored constituents, nitrite, nitrate, and phosphorus were not used in the HACA.

Cluster analysis requires that every sample contain values for all of the constituents listed in table 5. Seventeen incomplete samples were not used and are not reflected in the interpretation of results. The data set used for the HACA contained 409 samples.

In performing the HACA, the data were first log transformed. Log transformation results in data that are more constant in variance. The HACA routine also standardized the data. Each constituent was standardized by subtracting the constituent's mean value and dividing by the constituent's mean absolute deviation (Insightful Corporation, 2001). Log transformation followed by standardization results in each constituent value having a range of approximately -3 to +3 . This gives each constituent equal weight in the analysis; otherwise, the HACA algorithm would be affected most by constituents with large values. 
Table 5. Water-quality physical properties and constituents used in hierarchical agglomerative cluster analysis of water-quality samples from Lake Sakakawea, Audubon Lake, and McClusky Canal, central North Dakota, 1990-2003.

\begin{tabular}{ll}
\hline \multicolumn{1}{c}{ Constituent } & \multicolumn{1}{c}{ Unit } \\
\hline Specific conductance, field & Physical properties \\
$\mathrm{pH}$, field & Standard units \\
Alkalinity & Milligrams per liter as calcium carbonate \\
\hline & Major ions \\
\hline Calcium, dissolved & Milligrams per liter \\
Magnesium, dissolved & Milligrams per liter \\
Sodium, dissolved & Milligrams per liter \\
Potassium, dissolved & Milligrams per liter \\
Sulfate, dissolved & Milligrams per liter \\
Chloride, dissolved & Milligrams per liter \\
\hline & Nutrient \\
\hline Ammonia, dissolved & Milligrams per liter as nitrogen \\
\hline
\end{tabular}

In HACA, each sample forms its own cluster, and then pairs of clusters are successively merged on the basis of similarity of measurement and a linkage method. There are $\mathrm{N}-1$, or 408 , (where $\mathrm{N}$ is the total sample size, 409) merges in which the closest two clusters are merged into a single cluster, resulting in one less cluster at that merge. In this analysis, the similarity was computed by the Euclidean distance between samples. The Euclidean distance is the straight-line distance between two points in c-dimensional space defined by c variables. Here, $\mathrm{c}$ is 10 representing the 10 water-quality properties and constituents listed in table 5. Two points that have very similar values for all 10 constituents would lie close to each other if plotted in 10-dimensional space and, therefore, would have a small Euclidean distance between them and they would cluster together.

The linkage used to merge clusters was Ward's method. Ward's method uses an analysis of variance (ANOVA) approach to evaluate differences between clusters (Güler and others, 2002). The two clusters that are merged are the pair "that leads to the smallest increase in the sum of the withingroup sums of squares" (Insightful Corporation, 2001). The within-group sum of squares is the sum of the squared Euclidean distances from each sample to the center of its parent group.

To test statistical significance, the Kruskal-Wallis rank sum test (Higgins, 2004) was used. The Kruskal-Wallis rank sum test is a nonparametric test, meaning it does not assume that the data follow a particular distribution, such as the normal distribution. The differences in sampling periods of record, in the number of samples, and in the operational conditions at different sites in the study do not support the assumption that the samples all follow the same distribution. The
Kruskal-Wallis test compares data in more than two groups. When only two groups are compared, the Kruskal-Wallis rank sum test reduces to the Wilcoxson rank sum test (Higgins, 2004).

\section{Results of Hierarchical Agglomerative Cluster Analysis}

HACA results in a dendrogram and an agglomerative coefficient. A dendrogram is a "highly interpretable complete description of the hierarchical clustering in a graphical format" and "is one of the main reasons for the popularity of hierarchical clustering methods" (Hastie and others, 2001). The dendrogram resulting from HACA of the water-quality data in this study is shown in figure 5. The individual samples are represented by the vertical lines arranged so that branches of the dendrogram do not cross. The merges of similar clusters are represented by horizontal lines connecting clusters. The y-axis represents the distance between the two clusters being merged. Clusters that do not merge until the upper end of the $y$-axis represent water-quality samples that are distant from each other in Euclidean distance, that is samples that have widely differing constituent concentrations.

The agglomerative coefficient (AC) is a dimensionless quality index for measuring the clustering structure of the data set and is between 0 and 1 . The AC tends to increase with the number of samples; therefore, one should not compare the AC of different data sets that are very different in size (Struyf and others, 1997; Insightful Corporation, 2001). The agglomerative coefficient of the HACA in this study was high, 0.989 . 


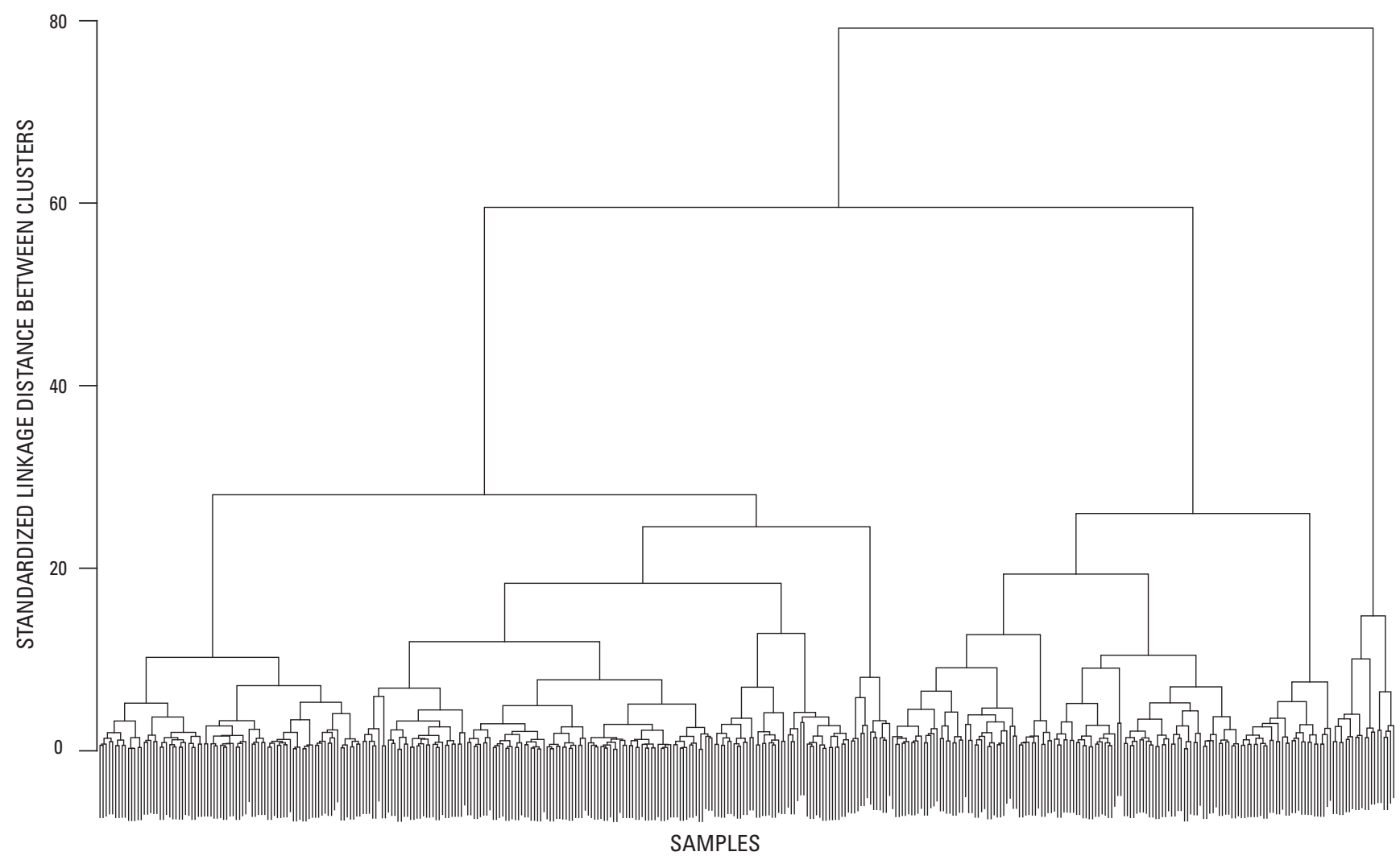

Figure 5. Dendrogram from hierarchical agglomerative cluster analysis of 409 surface-water samples collected from Lake Sakakawea, Audubon Lake, and McClusky Canal, 1990-2003. [Samples arranged so that branches of dendrogram do not cross.]

An AC close to 1 indicates that there is a "very clear clustering structure" in the data; however, the structure needs to be analyzed to determine that it is reasonable (Kaufman and Rousseeuw, 1990).

\section{Cluster Groups}

Examination of figure 5 led to the identification of three major branches in the dendrogram. These three branches represent three major cluster groups, labeled as A, B, and C in figure 6. A, B, and $\mathrm{C}$ were identified as major cluster groups because the linkage distance at which they combine with each other is relatively large, indicating that there are relatively large Euclidean distances between the samples in groups A, $\mathrm{B}$, and $\mathrm{C}$. The linkage distance at which groups $\mathrm{A}$ and $\mathrm{B}$ are combined is less than the linkage distance at which group $\mathrm{C}$ combines with the rest of the data, indicating that samples in groups A and B are more similar to each other than to the samples in group $C$. The samples in group $C$ do not merge with the rest of the samples until the final, $\mathrm{N}-1$, step of the algorithm.

Subgroups may be examined within these three main groups. The number of subgroups examined is subjective in that the analyst determines the number of subgroups by balancing interest in interpretable subgroups and avoidance of needless splitting of the data. One determines the number of subgroups examined by drawing a line across the dendrogram and examining the main clusters branching out beneath that line. By means of a dashed horizontal line, figure 6 shows the data divided into six subgroups (1-6). The groups and subgroups can be examined for spatial and temporal differences in sample membership and statistically significant differences in water-quality constituents.

\section{Major Cluster Groups}

Initial examination of the sample cluster groups indicated that differences in groups may be attributable to canal operations and the distance from the source water. Therefore, table 6 lists the water-quality sites in order by canal mile. The table also lists the number of samples at each site, and the percentage of samples at each site clustered into each major group.

Group A consists of 250 of the 409 samples and contains all of the samples from sites $3 \mathrm{~A}, 8 \mathrm{D}, 8 \mathrm{E}, 8 \mathrm{~F}, 8 \mathrm{G}, 3 \mathrm{~B}-1,3 \mathrm{~B}-2$, $3 \mathrm{C}$, and 3E-1. Group A contains no samples from sites 3I-1, $3 \mathrm{I}-2,3 \mathrm{~K}$, and $3 \mathrm{~J}$, those farthest from the source of water. Sites $3 \mathrm{~B}-2$ to $3 \mathrm{E}-1$ correspond to the section of the canal designated as section WS 1. Water levels in section WS 1 are kept at a higher elevation than the next downstream section of the canal, and the section is part of the canal freshening program (as is section WS 2). 


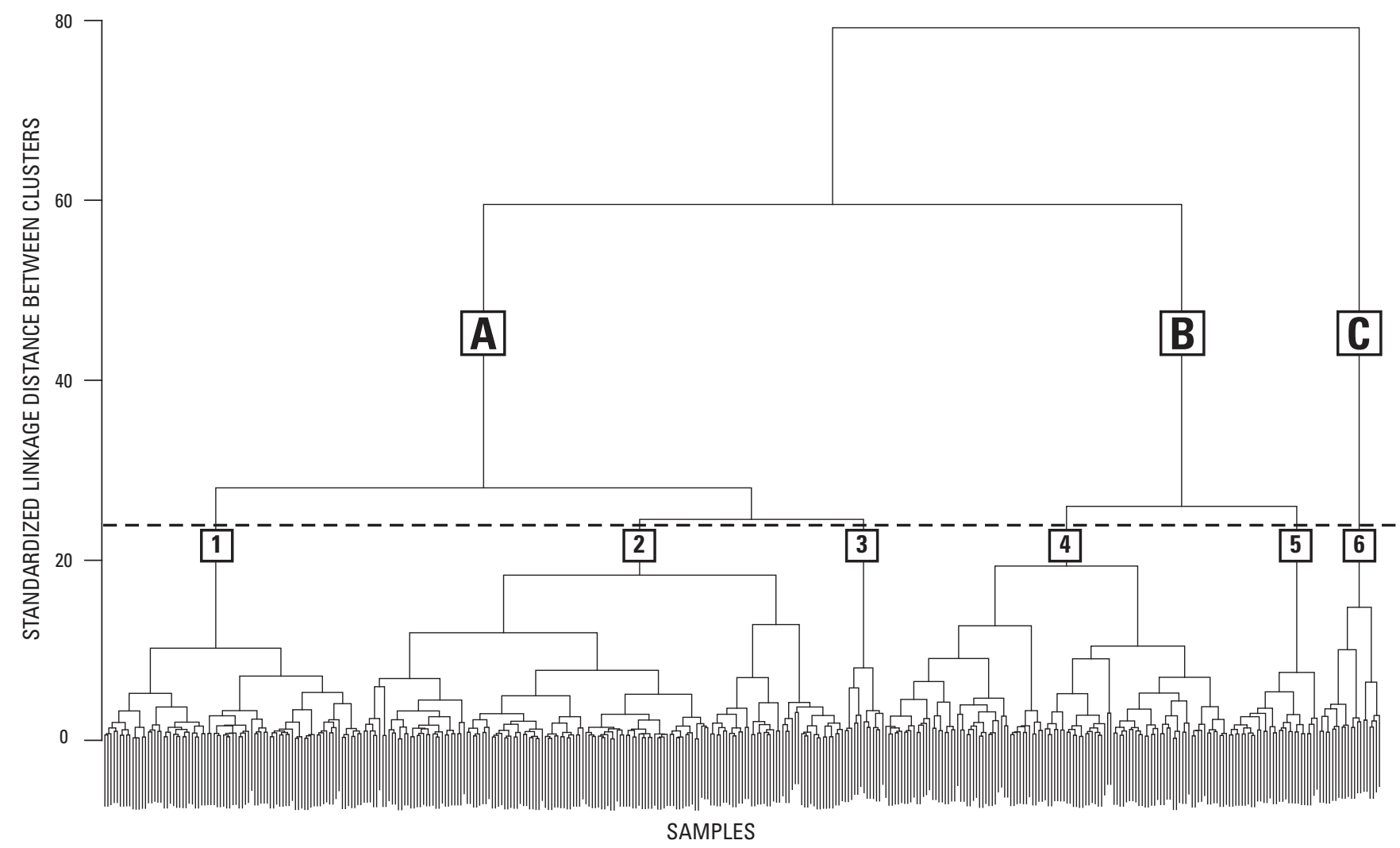

Figure 6. Dendrogram showing groups $(A, B$, and $C)$ and subgroups (1-6) of surface-water samples examined in this study. The dashed horizontal line identifies the six subgroups and those clusters whose main branches extend below the line. [Samples arranged so that branches of dendrogram do not cross.]

Table 6. Water-quality sampling sites on Lake Sakakawea, Audubon Lake, and McClusky Canal, central North Dakota, and percentage of samples that fall into cluster groups $A, B$, and C.

[Sites are listed in downstream order; map numbers are the Bureau of Reclamation site identification numbers; ft, feet; --, not applicable]

Percentage of samples in

\begin{tabular}{|c|c|c|c|c|c|c|}
\hline $\begin{array}{l}\text { Map number } \\
\text { (fig. 2) }\end{array}$ & Site description & Canal mile & $\begin{array}{l}\text { Total number } \\
\text { of samples }\end{array}$ & Group A & Group B & Group C \\
\hline $3 \mathrm{~A}$ & $\begin{array}{l}\text { Lake Sakakawea at Snake Creek Pump- } \\
\text { ing Plant (off west side of structure) }\end{array}$ & -- & 36 & 100.0 & -- & -- \\
\hline $8 \mathrm{D}$ & $\begin{array}{l}\text { Audubon National Wildlife Refuge } \\
\text { boundary line no. } 2 \text { buoy from } \\
\text { U.S. Highway } 83 \text {. }\end{array}$ & -- & 12 & 100.0 & -- & -- \\
\hline $8 \mathrm{~F}$ & $\begin{array}{l}\text { Audubon National Wildlife Refuge } \\
\text { boundary line no. } 15 \text { buoy from } \\
\text { U.S. Highway } 83 \text {. }\end{array}$ & -- & 11 & 100.0 & -- & -- \\
\hline
\end{tabular}


Table 6. Water-quality sampling sites on Lake Sakakawea, Audubon Lake, and McClusky Canal, central North Dakota, and percentage of samples that fall into cluster groups A, B, and C. - Continued

[Sites are listed in downstream order; map numbers are the Bureau of Reclamation site identification numbers; ft, feet; --, not applicable]

Percentage of samples in

\begin{tabular}{|c|c|c|c|c|c|c|}
\hline $\begin{array}{l}\text { Map number } \\
\text { (fig. 2) }\end{array}$ & Site description & Canal mile & $\begin{array}{l}\text { Total number } \\
\text { of samples }\end{array}$ & Group A & Group B & Group C \\
\hline $3 \mathrm{~B}-1$ & $\begin{array}{l}\text { McClusky Canal headworks at Lake } \\
\text { Audubon (inlet to canal) }\end{array}$ & 0 & 21 & 100.0 & -- & - \\
\hline $3 \mathrm{~B}-2$ & $\begin{array}{l}\text { McClusky Canal headworks } \\
\text { (downstream side of gates) }\end{array}$ & 0.2 & 28 & 100.0 & -- & -- \\
\hline $3 \mathrm{C}$ & $\begin{array}{l}\text { McClusky Canal at Lake Brekken } \\
\text { turnout (State Highway } 41 \text { north } \\
\text { of Turtle Lake) }\end{array}$ & 11.1 & 24 & 100.0 & -- & -- \\
\hline $3 \mathrm{E}-1$ & $\begin{array}{l}\text { McClusky Canal at radial gate } \\
\text { (R1 \& R2, upstream) }\end{array}$ & 19.9 & 4 & 100.0 & -- & -- \\
\hline $3 \mathrm{E}-2$ & $\begin{array}{l}\text { McClusky Canal bridge south of radial } \\
\text { gate (R1 \& R2, downstream) }\end{array}$ & 20.0 & 16 & 93.8 & 6.3 & -- \\
\hline $8 \mathrm{I}$ & Hecker's Lake out from canal & 34.2 & 31 & 61.3 & 38.7 & -- \\
\hline $8 \mathrm{H}$ & New Johns Lake west end & 35.0 & 18 & 77.8 & 22.2 & -- \\
\hline $1 \mathrm{E}-1$ & $\begin{array}{l}\text { Painted Woods Creek outlet channel } \\
\text { from New Johns Lake (at structure) }\end{array}$ & 36.0 & 13 & 76.9 & 23.1 & -- \\
\hline $1 \mathrm{E}-2$ & $\begin{array}{l}\text { Painted Woods Creek outlet channel } \\
\text { from New Johns Lake (lakeside) }\end{array}$ & 36.0 & 20 & 25.0 & 75.0 & -- \\
\hline $3 \mathrm{G}-3$ & $\begin{array}{l}\text { East end of New Johns Lake } \\
\quad(1 / 4 \text { mile west of canal } 400 \mathrm{ft} \text { south- } \\
\text { east of boat ramp) }\end{array}$ & 37.8 & 18 & 77.8 & 22.2 & -- \\
\hline $3 \mathrm{G}-1$ & $\begin{array}{l}\text { McClusky Canal radial gate } \\
\text { (west side) }\end{array}$ & 38.1 & 12 & 75.0 & 25.0 & -- \\
\hline $3 \mathrm{G}-2$ & $\begin{array}{l}\text { McClusky Canal bridge } \\
\text { (downstream of radial gate) }\end{array}$ & 38.4 & 9 & 55.6 & 44.4 & -- \\
\hline $3 \mathrm{H}-1$ & McClusky Canal plug (upstream) & 51.2 & 19 & 5.3 & 94.7 & -- \\
\hline $3 \mathrm{H}-2$ & McClusky Canal plug (downstream) & 51.3 & 17 & 5.9 & 94.1 & -- \\
\hline $3 \mathrm{I}-1$ & $\begin{array}{l}\text { McClusky Canal gate at State Highway } \\
200 \text { (upstream) }\end{array}$ & 54.9 & 22 & -- & 100.0 & -- \\
\hline $3 \mathrm{I}-2$ & $\begin{array}{l}\text { McClusky Canal gate at State Highway } \\
200 \text { (downstream) }\end{array}$ & 55.0 & 11 & -- & 100.0 & -- \\
\hline $3 \mathrm{~K}$ & $\begin{array}{l}\text { McClusky Canal at Hoffer Lake } \\
\text { (southeast of canal mile } 58 \text { plug at } \\
\text { boat dock) }\end{array}$ & 58.0 & 26 & -- & 96.2 & 3.8 \\
\hline $3 \mathrm{~J}$ & McClusky Canal plug (upstream) & 58.8 & 20 & -- & 5.0 & 95.0 \\
\hline
\end{tabular}


Downstream from the radial gate between sites 3E-1 and 3E-2, samples begin to cluster in groups A and B. Group B consists of 139 of the 409 samples. The split between group A and group B appears to be both spatial and temporal. For site 3G-2, samples from 1991 through 1993 clustered in group A, whereas samples from 1994 through 1996 clustered in group B. Water-quality samples from site 3G-3 prior to 1995 clustered in group $\mathrm{A}$, and the remainder of the samples from site 3G-3 clustered in group B. Almost all samples from sites $3 \mathrm{H}-1$ and $3 \mathrm{H}-2$ clustered in group $\mathrm{B}$, with the few clustering in group A being collected during the early 1990s. Canal operations may have contributed to the temporal differences in water quality. From 1993 through 1999, flows through the canal were shut down for about 2 months during July through September and the water-surface elevation in section WS 1 dropped $8 \mathrm{ft}$. This was done to allow "beachbelting" work, during which rock rip-rap was installed to stabilize the banks of the canal along the waterline of the desired operational water-surface elevation $(1,843.0$ to $1,845.5 \mathrm{ft}$ for section WS 1). Each fall, during the years in which beachbelting occurred, the water-surface elevation was brought back up before freezeup (M. Marohl, Bureau of Reclamation, oral commun., 2006).
In addition to beachbelting, another change in section WS 2 may help explain the temporal difference in water quality. The North Dakota State Game and Fish Department requested in 1993 that total dissolved-solids (TDS) concentrations in water from section WS 2, the Chain of Lakes, be increased (M. Marohl, Bureau of Reclamation, oral commun., 2006), using TDS concentration as a measure of dissolved ions necessary for the maintenance of aquatic life. TDS concentrations were increased by reducing releases of water from section WS 2 to the Painted Woods Creek outlet channel. In figure 7, TDS concentrations are plotted as points for the sampling sites located in section WS 2 from 1990 through 2003. The line is a Lowess scatterplot smooth (Insightful Corporation, 2002) of the TDS concentrations. TDS concentrations for sites in section WS 2 are listed in table 7 (at back of report). The number of samples and period of record vary at each site; however, TDS concentration in 1993-2003 is generally higher than TDS concentration in 1990-1992 for all sites except 3E-2. Because TDS can be correlated with specific conductance and the ions used in the HACA, a change in TDS concentrations can be related to a change in the variables used in the HACA and may contribute to the clustering of the data. For some of the sampling sites in the Chain of Lakes section, there was

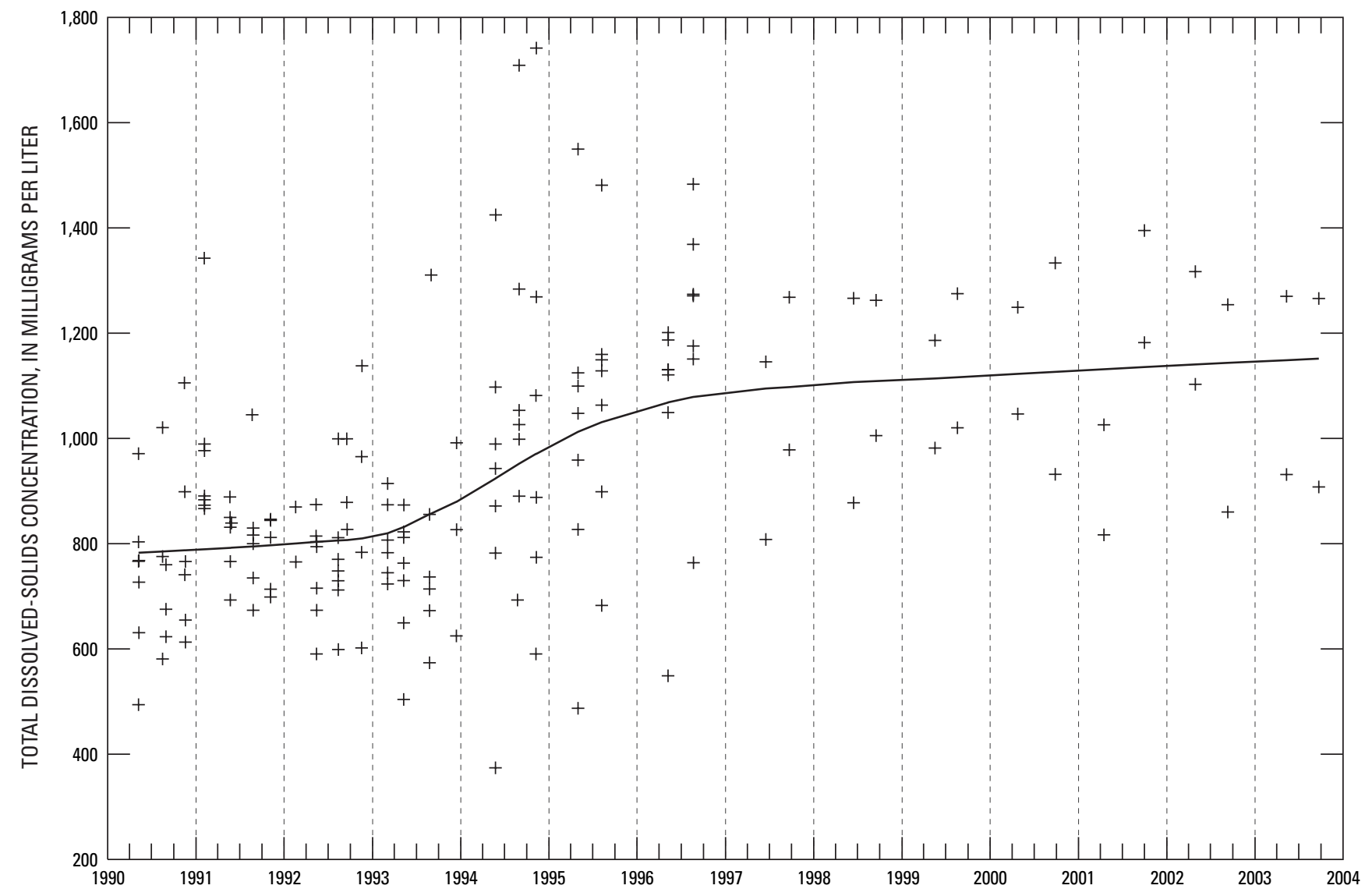

Figure 7. Total dissolved-solids concentrations in samples from water-quality sampling sites located in section WS 2, 1990-2003. The line is a Lowess scatterplot smooth used to exhibit the increase in total dissolved-solids concentrations that began in 1993. 
a change in clustering of the data that corresponded to the increase in TDS. For example, for site 1E-2, samples from 1990-91 were grouped in cluster A, and samples from 19942003 were grouped in cluster B.

Samples from sites 3I-1 and 3I-2 occurred only in group B, and of the 26 samples from site $3 \mathrm{~K}$ (table 1), 25 of them clustered in group B. These sampling sites are among those farthest from the source of water and are in the part of the canal that was filled by surface-water runoff and groundwater contributions.

Group C consists of 20 of the 409 samples. Of the 20 samples collected at site $3 \mathrm{~J}, 19$ of them occurred in group C. Group C contained only one sample from any other site, the May 26, 1994, sample from site 3K. This indicates that samples from site $3 \mathrm{~J}$ are similar to each other but dissimilar to samples from other sites. The segment of the canal between sites 3K and 3J, section WS 6, is known as Skunk Lake. Water in this segment is from surface-water runoff and ground-water contribution. There is no mechanical freshening mechanism for this segment, and the stagnant water would explain the high concentrations of water-quality constituents at site $3 \mathrm{~J}$.

\section{Cluster Subgroups}

The sites in order by canal mile, number of samples from each site used in the HACA, and the percentages of samples that fall into each subgroup are listed in table 8 (at back of report). Some of the water-quality differences are spatial (table 8); however, much of the difference between subgroups also may be temporal.

Subgroup 1 contains 83 of the 409 samples used in this study. For many sampling sites that have samples split between groups A and B, there appears to be a temporal difference in water quality. For example, most of the samples from site 3G-2 that were collected early in the period of record (1991-93) clustered into subgroup 1. The samples collected later in the period of record (1994-96) clustered into subgroup 4. Water quality in samples from site 3G-3 were similar in that most samples collected during 1990-95 clustered in subgroup 1 and samples collected during 1995-96 clustered in subgroup 4. The majority of samples in subgroup 1 were collected during 1990-93. This period corresponds to the part of this study in which water-quality samples were collected before beachbelting began in canal section WS 1 and before the increase in total dissolved-solids concentrations in section WS 2.

Subgroup 2 is the largest subgroup and contains 154 of the 409 samples. Subgroup 2 contains all samples from sites
$3 \mathrm{~B}-1$ and $3 \mathrm{E}-1$ and the majority of samples from sites $3 \mathrm{~A}, 8 \mathrm{D}$, $8 \mathrm{E}, 8 \mathrm{~F}, 8 \mathrm{G}, 3 \mathrm{~B}-2,3 \mathrm{C}$, and $3 \mathrm{E}-2$. These are the sites closest to the source water. Sample membership in this group generally spans the period of record for each sampling site.

Subgroup 3 contains 13 of the 409 samples. Most of the samples in this group are from sites $3 \mathrm{~A}$. Subgroup membership appears to be related to time. Subgroup 2 contains samples collected early in the period of record and late in the period of record for site 3A (1990-92 and 2002-03).

Some of the differences in subgroups 1-3 may be seasonal. However, this is difficult to examine because of the different periods of record at sites and different sampling dates from year to year. For example, it appears that samples collected in February were more likely to cluster into subgroup 1; however, February samples were collected only in 1991 and 1992. Likewise, March samples were collected only in 1993 and 1994.

Subgroup 4 contains 110 of 409 samples. Samples collected at sites 3I-1, 3I-2, and 3K were split between subgroups 4 and 5 (with the exception of the one sample from site $3 \mathrm{~K}$ in subgroup 6). The differences in water quality among samples in subgroups 4 and 5 appear to be temporal. For example subgroup 4 contains samples collected from site $3 \mathrm{~K}$ during 1995-2003.

Subgroup 5 contains 29 of 409 samples, none of which were collected during 1996-2001. Samples from site 3K were collected during 1992-95 and 2002-03. These years correspond to the beginning and end of the period of record. For samples from site 3I-1, which occurred only in group B, samples in subgroup 5 were collected early in the period of record (1990-91 and 1994) and late in the period of record (2002-03). Samples from site 3I-2 also clustered only in group B; however, the period of record for site 3I-2 ended in 1995, and samples from the middle part of the period of record (1991-94) occurred in subgroup 5.

At the linkage distance chosen to identify subgroups for analysis (fig. 6), Group C was not subdivided further. Group $\mathrm{C}$ and subgroup 6 have the same sample membership and are representative of water quality at site $3 \mathrm{~J}$ during the study period.

\section{Inter-Subgroup Comparison}

Mean concentrations for samples in subgroup clusters 1-6 for all of the uncensored constituents used in the HACA plus total dissolved solids are listed in table 9. Nitrite, nitrate, and phosphorus were highly censored and were not used in the HACA. Ammonia values also were censored, but to a lesser extent, so ammonia concentrations were used in the HACA. 


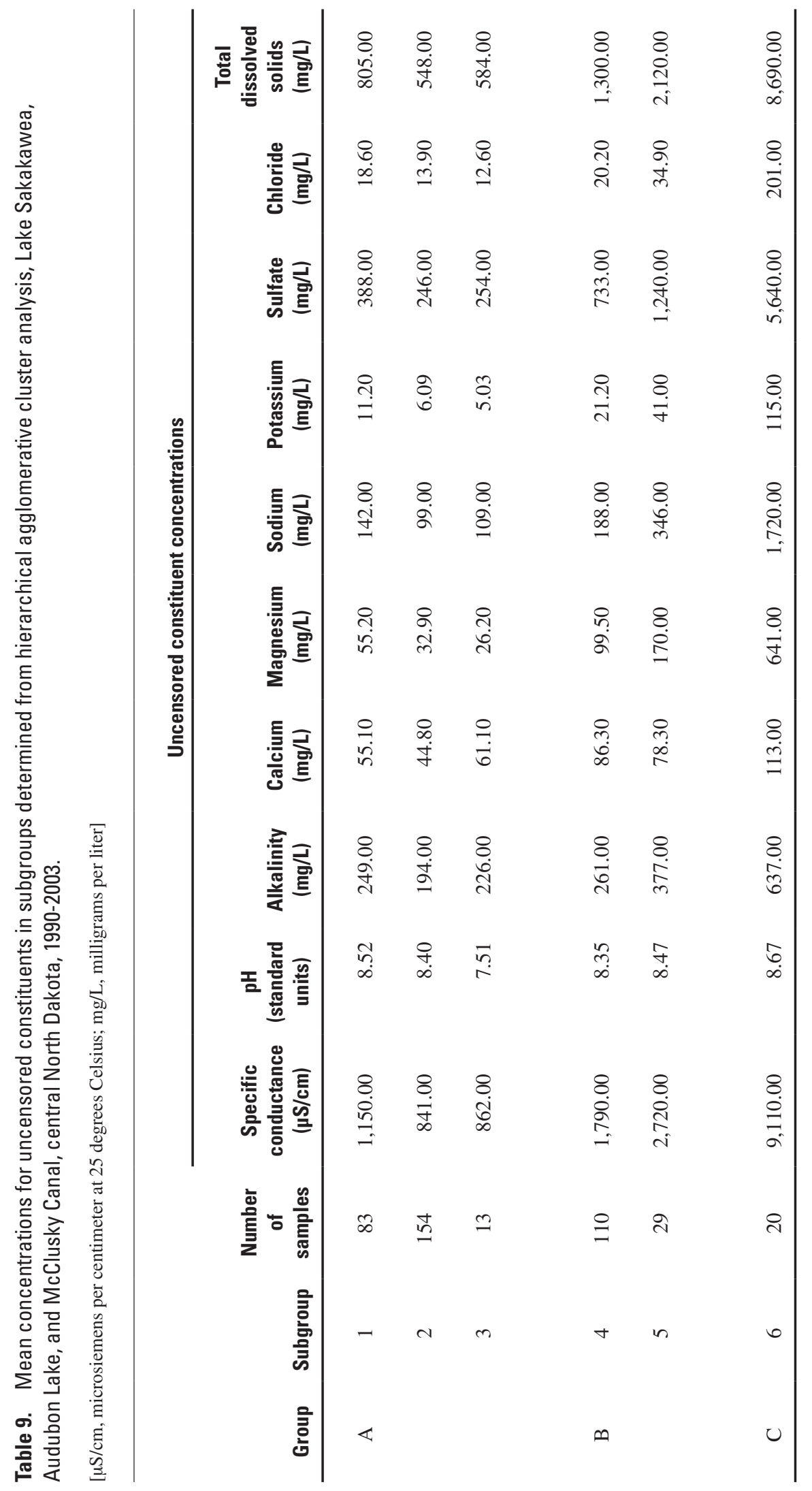


A summary of the cluster medians for the censored constituents is shown in table 10. For those clusters in which a constituent was more than 80 percent censored, the percentage of censored values is shown. To calculate summary statistics for censored constituents with less than 80 percent of the values censored, Helsel's (2005) methods and guidelines were followed. For subgroups in which less than 50 percent of the values were censored, the median is a Kaplan-Meier estimate of the median. The subgroup median concentrations estimated by Kaplan-Meier are followed by a KM subscript. When 50-80 percent of the values in a subgroup were censored, the median concentration is a ROS estimate of the median. The subgroup median concentrations estimated by ROS are followed by an ROS subscript. For four subgroups in which there were no censored ammonia values, the actual median concentration is shown.

\section{Statistical Testing}

Nonparametric rank tests were performed at the 0.01 significance level to test whether all populations (group or subgroups) have the same distribution function or at least one of the populations has a different location (median). Results of the test for statistical significance are summarized in table 11.
The test for statistical significance was first performed on groups A, B, and C, to determine if there was a statistically significant difference in at least one of these groups. The p-values of the test performed for each uncensored constituent appear in table 11. The p-values were all less than 0.01 , indicating that there is a significant statistical difference in all uncensored constituent concentrations used in the HACA and in TDS concentrations.

Next, a test of significance was performed for the subgroups in group A and the subgroups in group B. All uncensored constituents and total dissolved solids had statistically significant differences in group A, indicating that at least one of the subgroups, 1,2 , or 3 , is different from the others. For Group B, the p-value for calcium was 0.062 (table 11). This means if the data in subgroups 4 and 5 were repeatedly randomly assigned to either subgroup, 6.2 percent of random assignments would result in the calcium values found in this study. The p-value for $\mathrm{pH}$ was 0.010 . All other constituents in group B had a statistically significant difference with p-values less than 0.01 .

Tests of significance were performed on subgroups 1,2 , and 3 of group A to determine which subgroups differed from the others. The p-values for these tests are shown in table 12.

Table 10. Median concentrations for censored constituents in subgroups determined from hierarchical agglomerative cluster analysis, Lake Sakakawea, Audubon Lake, and McClusky Canal, central North Dakota, 1990-2003.

$[\mathrm{mg} / \mathrm{L}$, milligrams per liter]

\begin{tabular}{|c|c|c|c|c|c|c|}
\hline \multirow[b]{2}{*}{ Group } & \multirow[b]{2}{*}{ Cluster } & \multirow[b]{2}{*}{$\begin{array}{l}\text { Number of } \\
\text { samples }\end{array}$} & \multicolumn{4}{|c|}{$\begin{array}{l}\text { Censored constituent concentrations, in milligrams per liter }(\mathrm{mg} / \mathrm{L}) \text {, or } \\
\text { percentage }(\%) \text { of censored values }{ }^{1,2,3}\end{array}$} \\
\hline & & & $\begin{array}{c}\text { Nitrite } \\
\text { (censored at } \\
0.02 \mathrm{mg} / \mathrm{L} \text { ) }\end{array}$ & $\begin{array}{c}\text { Nitrate } \\
\text { (censored at } \\
0.10 \mathrm{mg} / \mathrm{L} \text { ) }\end{array}$ & $\begin{array}{c}\text { Ammonia }^{4} \\
\text { (censored at } \\
0.02 \mathrm{mg} / \mathrm{L} \text { ) }\end{array}$ & $\begin{array}{c}\text { Phosphorus } \\
\text { (censored at } \\
0.01 \mathrm{mg} / \mathrm{L} \text { ) }\end{array}$ \\
\hline \multirow[t]{3}{*}{ A } & 1 & 83 & $86.6 \%$ & $95.1 \%$ & 0.150 & $0.008_{\mathrm{ROS}}$ \\
\hline & 2 & 154 & $97.4 \%$ & $0.042_{\mathrm{ROS}}$ & $0.120_{\mathrm{KM}}$ & $0.010_{\mathrm{ROS}}$ \\
\hline & 3 & 13 & $92.3 \%$ & $0.100_{\text {Км }}$ & 0.250 & $0.010_{\mathrm{KM}}$ \\
\hline \multirow[t]{2}{*}{ B } & 4 & 110 & $97.3 \%$ & $83.6 \%$ & $0.100_{\mathrm{KM}}$ & $0.006_{\mathrm{ROS}}$ \\
\hline & 5 & 29 & $93.1 \%$ & $82.8 \%$ & 0.330 & $0.010_{\mathrm{KM}}$ \\
\hline $\mathrm{C}$ & 6 & 20 & $0.009_{\mathrm{ROS}}$ & $85.0 \%$ & 0.845 & $0.050_{\mathrm{KM}}$ \\
\hline
\end{tabular}

${ }^{1}$ When 80 percent or more of values are censored, the percentage of censored values is displayed.

${ }^{2}$ When censoring occurs, but less than 50 percent of the values are censored, the median is a Kaplan-Meier (KM) estimate of the median.

${ }^{3}$ When $50-80$ percent of the values are censored, the median is a regression on order statistics (ROS) estimate of the median.

${ }^{4}$ Actual medians are shown for subgroups $1,2,5$, and 6, which contained no censored values. 

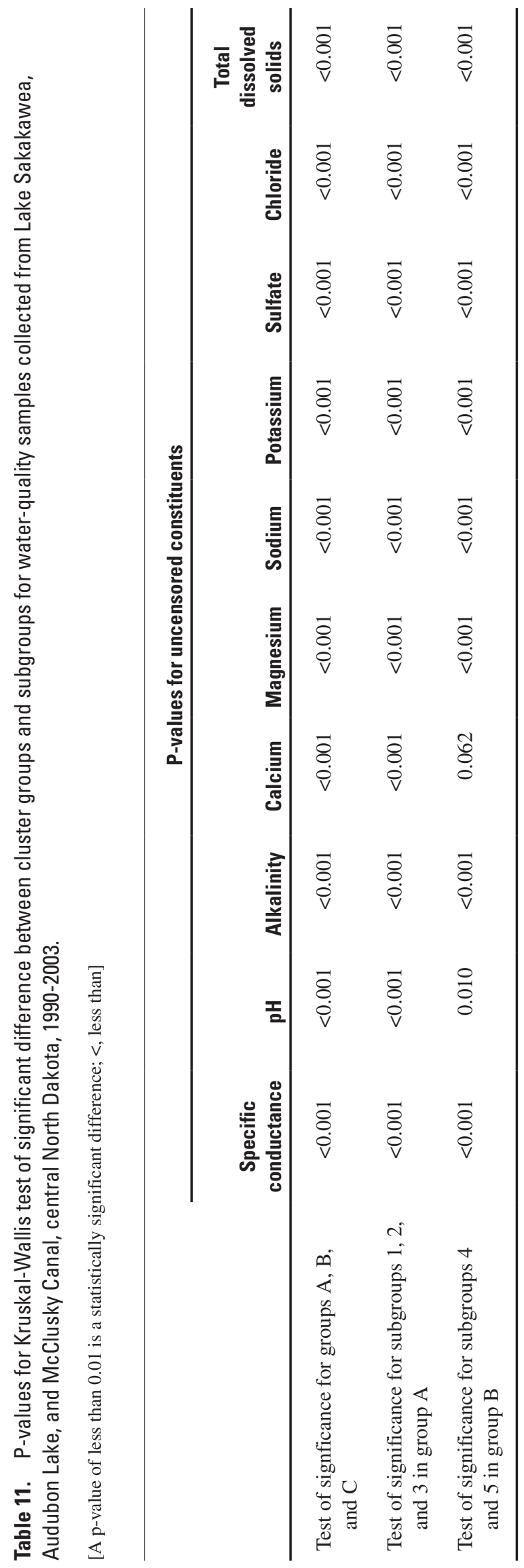

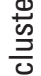

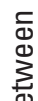

๑

ฮั

责

若

栲 든

혼은

嵌

की

言市

$\frac{1}{\pi} \pi$

क्

立吾.

产造

寻 亭 苛

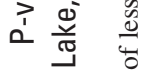

흘

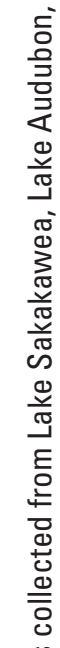

过

胥

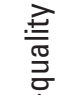

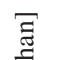

迹

¿

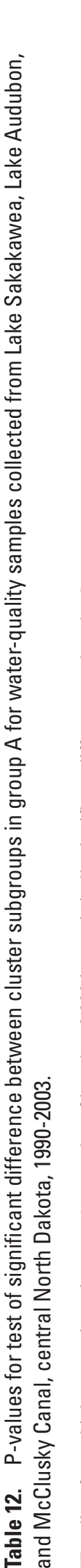


Doing multiple comparisons within a group results in an increased experiment-wise error rate. To control this error rate, the $\mathrm{p}$-value indicating a statistically significant difference was defined as 0.003 . Subgroups 1 and 2 were statistically different for every constituent. Subgroups 1 and 3 were statistically different for all constituents except alkalinity (p-value 0.017, table 12) and calcium (p-value 0.082, table 12).

In examining the subgroup mean concentrations for each constituent, subgroups 2 and 3 appeared to be similar. Above the dashed line in the dendrogram (fig. 6), subgroups 2 and 3 combine at the lowest linkage distance of the cluster merges, indicating that subgroups 2 and 3 are the most similar of the six subgroups identified. Subgroups 2 and 3 were not statistically different for specific conductance, alkalinity, sodium, potassium, sulfate, chloride, and total dissolved solids ( $\mathrm{p}$-values $>0.003$, table 12). Subgroups 2 and 3 were significantly different for $\mathrm{pH}$, calcium, and magnesium.

\section{Future Water-Quality Sampling}

Water-quality samples were collected from four sites on Audubon Lake, sites 8D, 8E, 8F, and 8G. In this analysis, there was not a significant difference in constituent concentrations among these sites. All of the Audubon Lake samples fell into cluster group A, and the majority of samples fell into subgroup 2. The samples from the lake sites also were similar in that none of the samples at any Audubon Lake site fell into subgroup 3. Four samples, one from each Audubon Lake site, fell into subgroup 1. All four samples were collected on February 7,1991 . If water-quality sampling continues in the same manner that the sampling was done for this study, it would not be necessary to sample from the four lake sites because of the lack of variability between sites.

Examination of the clustering of sites in section WS 2 of the McClusky Canal also indicates the possibility of sampling at fewer sites. For example, site $8 \mathrm{H}$, the west end of $\mathrm{New}$ Johns Lake, and site 3G-3, the east end of New Johns Lake, had the same sample size, period of record, and the same clustering structure. The clustering structure of the two sites indicates a lack of variability between the two sites. Other sites in section WS 2, 1E-1 and 3G-1, cluster in a similar manner; however, their differing sample sizes and periods of record make direct comparison difficult.

The clustering of the McClusky Canal water-quality samples and past operations of the canal suggest that water quality changes in response to operational changes. Future operational changes, such as the canal being used to transport water for the RRVWSP, may justify additional water-quality sampling to characterize possible water-quality changes.

\section{Summary}

As a result of the Dakota Water Resources Act of 2000, the Bureau of Reclamation, U.S. Department of the Interior, identified eight water-supply alternatives (including a noaction alternative) for the Red River Valley Water Supply Project. Of those alternatives, four included the interbasin transfer of water, three of which would use the McClusky Canal to transport the water. Therefore, the water quality of the McClusky Canal and its sources, Lake Sakakawea and Audubon Lake, is of interest to water-quality stakeholders.

This report summarizes water-quality data collected by the Bureau of Reclamation at 23 sites on Lake Sakakawea, Audubon Lake, and the McClusky Canal system. Results of sample analysis were interpreted by the U.S. Geological Survey using hierarchical agglomerative cluster analysis (HACA). HACA clustered the 409 samples into related groups based on physical properties, specific conductance, $\mathrm{pH}$, and alkalinity, and water-quality constituents, calcium, magnesium, sodium, potassium, sulfate, chloride, and ammonia. The HACA indicated that the samples had a strong clustering structure.

The samples clustered into three main groups that had statistically significant differences for all physical properties and constituents used in the HACA. Some of the differences corresponded to different sections of the canal that are under different operational conditions. Differences in operational conditions included sections of the canal, or water surfaces, separated by plugs or gates, that were held at different elevations and differences in source water. Some sections of the canal receive inflow from Audubon Lake and have an outlet to the next water surface (section WS 1) or Painted Woods Creek (section WS 2). Other sections receive water only through surface-water runoff and ground-water contribution and did not have a mechanical freshening mechanism (sections WS 4, 5, and 6).

Operational changes to the canal during specific periods also appeared to affect the clustering of the data. Examples of operational changes included beachbelting work done during 1993-99 that affected the elevation and flow in canal section WS 1 and also affected the flow of water through section WS 2. In addition, beginning in 1993, releases from section WS 2 to the Painted Woods Creek outlet channel were reduced to increase total dissolved-solids concentrations in section WS 2 at the request of the North Dakota Game and Fish Department.

The samples were examined further by looking at six subgroup clusters. These clusters also had statistically significant differences and appeared to correspond with operational changes and the water surfaces of the canal. The strong clustering structure and statistically significant differences in the HACA indicate that future water-quality sampling in response to operational changes in the McClusky Canal system would be justified to characterize possible water-quality changes. 


\section{References Cited}

Alther, G.A., 1979, A simplified statistical sequence applied to routine water quality analysis - a case history: Ground Water, v. 17, no. 6, p. 556-561.

Berkas, W.R., and Komor, S.C., 1996, Arsenic and selenium in soils and shallow ground water in the Turtle Lake, New Rockford, Harvey Pumping, Lincoln Valley, and LaMoure irrigation areas of the Garrison Diversion Unit, North Dakota: U.S. Geological Survey Water-Resources Investigations Report 96-4205, 197 p., accessed March 21, 2006, at http://pubs.er.usgs.gov/pubs/wri/wri964205

Briel, L.I., 1988, Summaries of water-quality data collected during 1979-87 for selected James River and refuge locations in North Dakota and South Dakota: U.S. Geological Survey Open-File Report 88-732, 197 p., accessed March 21, 2006, at http://pubs.er.usgs.gov/pubs/ofr/ ofr 88732

Briel, L.I., 1989, Dissolved-solids data for the James River salinity model, North Dakota and South Dakota: U.S. Geological Survey Open-File Report 89-43, 239 p., accessed March 21, 2006, at http://pubs.er.usgs.gov/pubs/ofr/ofr8943

Farnham, I.M., Klaus, J.S., Ashok, K.S., and Johannesson, K.H., 2000, Deciphering groundwater flow systems in Oasis Valley, Nevada, using trace element chemistry, multivariate statistics, and geographical information system: Mathematical Geology, v. 32, no. 8, p. 943-968.

Goolsby, D.A., Severson, R.C., Wilson, S.A., and Webber, Kurt, 1989, Geochemistry of soils and shallow ground water, with emphasis on arsenic and selenium, in part of the Garrison Diversion Unit, North Dakota, 1985-87: U.S. Geological Survey Water-Resources Investigations Report 89-4104, 132 p., accessed March 21, 2006, at http://pubs. er.usgs.gov/pubs/wri/wri894104

Guenthner, R.S., 1991, Methods for estimating monthly mean concentrations of selected water-quality constituents for stream sites in the Red River of the North Basin, North Dakota and Minnesota: U.S. Geological Survey WaterResources Investigations Report 91-4086, 113 p., accessed March 21, 2006, at http://pubs.er.usgs.gov/pubs/wri/ wri914086

Guenthner, R.S., 1993, Simulated effects of the proposed Garrison Diversion Unit on streamflow and dissolved solids in the Sheyenne River and the Red River of the North, North Dakota and Minnesota: U.S. Geological Survey Water-Resources Investigations Report 93-4200, 121 p., accessed March 21, 2006, at http://pubs.er.usgs.gov/pubs/ wri/wri934200
Güler, C., Thyne, G.D., McCray, J.E., and Turner, K.A., 2002, Evaluation of graphical and multivariate statistical methods for classification of water chemistry data: Hydrogeology Journal, v. 10, p. 455-474.

Hastie, T., Tibshirani, R., and Friedman, J., 2001, The elements of statistical learning — data mining, inference, and prediction: New York, Springer Science+Business Media, Inc., $533 \mathrm{p}$.

Helsel, D.R., 2005, Nondetects and data analysis: statistics for censored environmental data: Hoboken, New Jersey, John Wiley \& Sons, Inc., 250 p.

Higgins, J.J., 2004, Introduction to modern nonparametric statistics: Pacific Grove, California, Brooks/Cole-Thomson Learning, Inc., 366 p.

Insightful Corporation, 2001, S-PLUS 6 for Windows guide to statistics, volume 2, Seattle: Insightful Corporation, 622 p.

Insightful Corporation, 2002, S-PLUS 6.1 for Windows language reference: Seattle, Insightful Corporation, [variously paged].

Kaufman, L., and Rousseeuw, P.J., 1990, Finding groups in data-an introduction to cluster analysis: New York, John Wiley \& Sons, Inc., 342 p.

Sando, S.K., Guttormson, K.G., and Gleich, T.A., 1990, Water resources data collected during water year 1988 at selected James River Basin sites in North Dakota and South Dakota: U.S. Geological Survey Open-File Report 90-101, 230 p., accessed March 20, 2006, at http://pubs.er.usgs.gov/pubs/ ofr/ofr 90101

Sanford, R.F., Pierson, C.T., and Crovelli, R.A., 1993, An objective replacement method for censored geochemical data: Mathematical Geology, v. 25, no. 1, p. 59-80.

Struyf, A., Hubert, M., and Rousseeuw, P.J., 1997, Integrating robust clustering techniques in S-PLUS: Computational Statistics \& Data Analysis, v. 26, p. 17-37.

Troiano, J., Johnson, B.R., and Powell, S., 1994, Use of cluster and principal component analyses to profile areas in California where ground water has been contaminated by pesticides: Environmental Monitoring and Assessment, v. 32 , p. 269-288. 
U.S. Congress, 2000, Garrison Diversion Unit, Missouri River Basin Project, The Act of August 5, 1965 (Public Law 89-108, 79 Stat. 443) as amended by The Garrison Diversion Reformulation Act of 1986 (Public Law 99-294, 100 Stat. 418) and as further amended by Sec. 3510 and 1701 of the Reclamation Projects Authorization and Adjustment Act of 1992 (Public Law 102-575, 106 Stat. 4600) and as further amended by The Dakota Water Resources Act of 2000 (Public Law 106-554), accessed March 20, 2006, at http://www.garrisondiversion.org/media/dwrafinal.pdf
U.S. Department of the Interior, Bureau of Reclamation, 2005, Executive summary-Final report on Red River Valley water needs and options, 25 p., accessed March 15, 2006, at http://www.usbr.gov/gp/dkao/redriver/rrvwsp/Report/ Exec\%20Summary.pdf 
This page intentionally blank. 
Table 3. Summary statistics for uncensored water-quality physical properties and constituents at sampling sites on Lake Sakakawea, Audubon Lake, and McClusky Canal, central North Dakota, 1990-2003.

[Specific conductance in microsiemens per centimeter at 25 degrees Celsius; $\mathrm{pH}$ in standard units; other constituent concentrations in milligrams per liter]

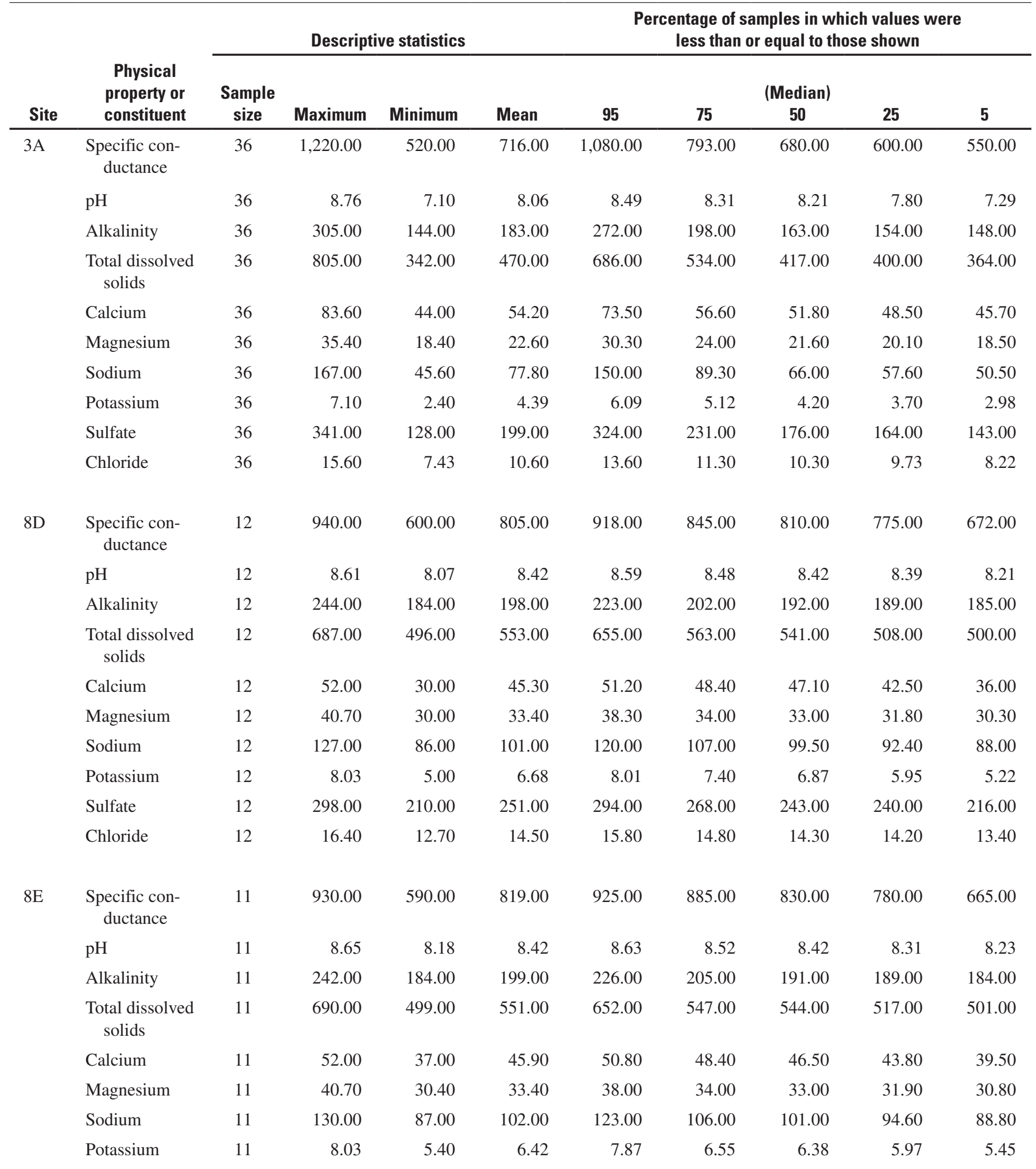


Table 3. Summary statistics for uncensored water-quality physical properties and constituents at sampling sites on Lake Sakakawea, Audubon Lake, and McClusky Canal, central North Dakota, 1990-2003. —Continued

[Specific conductance in microsiemens per centimeter at 25 degrees Celsius; $\mathrm{pH}$ in standard units; other constituent concentrations in milligrams per liter]

\begin{tabular}{|c|c|c|c|c|c|c|c|c|c|c|}
\hline \multirow[b]{2}{*}{ Site } & \multirow{2}{*}{$\begin{array}{l}\text { Physical } \\
\text { property or } \\
\text { constituent }\end{array}$} & \multicolumn{4}{|c|}{ Descriptive statistics } & \multicolumn{5}{|c|}{$\begin{array}{l}\text { Percentage of samples in which values were } \\
\text { less than or equal to those shown }\end{array}$} \\
\hline & & $\begin{array}{l}\text { Sample } \\
\text { size }\end{array}$ & Maximum & Minimum & Mean & 95 & 75 & $\begin{array}{c}\text { (Median) } \\
50\end{array}$ & 25 & 5 \\
\hline \multirow[t]{2}{*}{$8 \mathrm{E}$} & Sulfate & 11 & 300.00 & 215.00 & 249.00 & 289.00 & 256.00 & 242.00 & 240.00 & 219.00 \\
\hline & Chloride & 11 & 16.40 & 12.90 & 14.40 & 15.90 & 14.90 & 14.30 & 13.80 & 13.30 \\
\hline \multirow[t]{10}{*}{$8 \mathrm{~F}$} & $\begin{array}{l}\text { Specific con- } \\
\text { ductance }\end{array}$ & 11 & 940.00 & 640.00 & 836.00 & 935.00 & 890.00 & 840.00 & 810.00 & 710.00 \\
\hline & $\mathrm{pH}$ & 11 & 8.71 & 8.25 & 8.45 & 8.66 & 8.52 & 8.44 & 8.38 & 8.26 \\
\hline & Alkalinity & 11 & 236.00 & 185.00 & 199.00 & 221.00 & 203.00 & 195.00 & 191.00 & 186.00 \\
\hline & $\begin{array}{l}\text { Total dissolved } \\
\text { solids }\end{array}$ & 11 & 679.00 & 503.00 & 563.00 & 649.00 & 582.00 & 552.00 & 534.00 & 506.00 \\
\hline & Calcium & 11 & 52.00 & 40.00 & 46.10 & 50.80 & 48.30 & 46.60 & 44.30 & 40.50 \\
\hline & Magnesium & 11 & 39.60 & 30.60 & 34.10 & 37.40 & 34.20 & 34.00 & 33.50 & 31.50 \\
\hline & Sodium & 11 & 125.00 & 95.30 & 106.00 & 120.00 & 110.00 & 102.00 & 101.00 & 95.80 \\
\hline & Potassium & 11 & 7.48 & 5.70 & 6.38 & 7.39 & 6.60 & 6.30 & 5.88 & 5.75 \\
\hline & Sulfate & 11 & 299.00 & 237.00 & 258.00 & 293.00 & 272.00 & 248.00 & 244.00 & 238.00 \\
\hline & Chloride & 11 & 15.70 & 12.10 & 14.40 & 15.50 & 15.00 & 14.60 & 13.90 & 13.00 \\
\hline \multirow[t]{10}{*}{$8 \mathrm{G}$} & $\begin{array}{l}\text { Specific con- } \\
\text { ductance }\end{array}$ & 10 & 940.00 & 610.00 & 844.00 & 936.00 & 895.00 & 860.00 & 830.00 & 687.00 \\
\hline & $\mathrm{pH}$ & 10 & 8.66 & 8.23 & 8.46 & 8.63 & 8.54 & 8.46 & 8.42 & 8.24 \\
\hline & Alkalinity & 10 & 264.00 & 186.00 & 202.00 & 239.00 & 198.00 & 195.00 & 192.00 & 188.00 \\
\hline & $\begin{array}{l}\text { Total dissolved } \\
\text { solids }\end{array}$ & 10 & 703.00 & 506.00 & 558.00 & 639.00 & 556.00 & 554.00 & 535.00 & 507.00 \\
\hline & Calcium & 10 & 50.60 & 37.00 & 45.00 & 50.10 & 47.30 & 46.30 & 41.80 & 38.80 \\
\hline & Magnesium & 10 & 40.70 & 31.10 & 34.40 & 38.70 & 34.10 & 34.00 & 33.50 & 31.90 \\
\hline & Sodium & 10 & 130.00 & 93.60 & 105.00 & 123.00 & 109.00 & 104.00 & 97.70 & 94.70 \\
\hline & Potassium & 10 & 7.60 & 5.70 & 6.45 & 7.50 & 6.68 & 6.35 & 6.00 & 5.77 \\
\hline & Sulfate & 10 & 299.00 & 237.00 & 253.00 & 284.00 & 252.00 & 248.00 & 246.00 & 239.00 \\
\hline & Chloride & 10 & 16.10 & 14.00 & 14.70 & 15.70 & 14.90 & 14.60 & 14.40 & 14.10 \\
\hline \multirow[t]{6}{*}{$3 \mathrm{~B}-1$} & $\begin{array}{l}\text { Specific con- } \\
\text { ductance }\end{array}$ & 21 & $1,090.00$ & 640.00 & 892.00 & $1,010.00$ & 930.00 & 890.00 & 870.00 & 770.00 \\
\hline & $\mathrm{pH}$ & 21 & 8.74 & 7.79 & 8.43 & 8.73 & 8.59 & 8.45 & 8.38 & 8.04 \\
\hline & Alkalinity & 21 & 245.00 & 158.00 & 203.00 & 226.00 & 215.00 & 201.00 & 192.00 & 170.00 \\
\hline & $\begin{array}{l}\text { Total dissolved } \\
\text { solids }\end{array}$ & 21 & 690.00 & 444.00 & 577.00 & 634.00 & 599.00 & 583.00 & 557.00 & 508.00 \\
\hline & Calcium & 21 & 47.00 & 31.40 & 41.60 & 46.00 & 44.00 & 42.50 & 39.00 & 37.40 \\
\hline & Magnesium & 21 & 39.50 & 25.30 & 34.20 & 39.00 & 36.50 & 34.80 & 32.30 & 28.60 \\
\hline
\end{tabular}


Table 3. Summary statistics for uncensored water-quality physical properties and constituents at sampling sites on Lake Sakakawea, Audubon Lake, and McClusky Canal, central North Dakota, 1990-2003. _Continued

[Specific conductance in microsiemens per centimeter at 25 degrees Celsius; $\mathrm{pH}$ in standard units; other constituent concentrations in milligrams per liter]

\begin{tabular}{|c|c|c|c|c|c|c|c|c|c|c|}
\hline Site & $\begin{array}{l}\text { Physical } \\
\text { property or } \\
\text { constituent }\end{array}$ & \multicolumn{4}{|c|}{ Descriptive statistics } & \multicolumn{5}{|c|}{$\begin{array}{c}\text { Percentage of samples in which values were } \\
\text { less than or equal to those shown }\end{array}$} \\
\hline \multirow[t]{3}{*}{$3 \mathrm{~B}-1$} & Sodium & 21 & 130.00 & 76.20 & 104.00 & 114.00 & 110.00 & 107.00 & 99.80 & 82.00 \\
\hline & Potassium & 21 & 8.42 & 1.25 & 5.63 & 7.90 & 6.60 & 5.50 & 5.06 & 3.28 \\
\hline & Chloride & 21 & 18.30 & 11.60 & 14.80 & 17.80 & 15.50 & 15.30 & 13.60 & 11.80 \\
\hline \multirow[t]{7}{*}{$3 \mathrm{~B}-2$} & $\begin{array}{l}\text { Specific con- } \\
\text { ductance }\end{array}$ & 28 & $1,040.00$ & 610.00 & 891.00 & $1,010.00$ & 955.00 & 885.00 & 855.00 & 784.00 \\
\hline & Calcium & 28 & 73.10 & 33.00 & 44.40 & 59.10 & 45.80 & 43.00 & 40.20 & 37.10 \\
\hline & Magnesium & 28 & 48.90 & 31.40 & 36.30 & 45.90 & 36.80 & 35.10 & 34.30 & 31.90 \\
\hline & Sodium & 28 & 151.00 & 68.90 & 107.00 & 129.00 & 112.00 & 107.00 & 102.00 & 88.60 \\
\hline & Potassium & 28 & 8.47 & 3.93 & 6.08 & 8.12 & 6.90 & 6.30 & 5.01 & 4.06 \\
\hline & Sulfate & 28 & 392.00 & 215.00 & 268.00 & 344.00 & 276.00 & 263.00 & 247.00 & 227.00 \\
\hline & Chloride & 28 & 19.10 & 11.80 & 14.90 & 18.50 & 15.60 & 15.20 & 13.90 & 12.30 \\
\hline \multirow[t]{6}{*}{$3 \mathrm{C}$} & $\begin{array}{l}\text { Specific con- } \\
\text { ductance }\end{array}$ & 24 & $1,600.00$ & 660.00 & 934.00 & $1,100.00$ & 975.00 & 920.00 & 858.00 & 690.00 \\
\hline & Magnesium & 24 & 47.30 & 28.80 & 35.60 & 42.90 & 37.30 & 35.10 & 33.50 & 29.10 \\
\hline & Sodium & 24 & 153.00 & 76.00 & 109.00 & 131.00 & 116.00 & 110.00 & 102.00 & 80.10 \\
\hline & Potassium & 24 & 8.90 & 5.00 & 6.82 & 8.59 & 7.52 & 6.85 & 6.07 & 5.51 \\
\hline & Sulfate & 24 & 360.00 & 181.00 & 263.00 & 312.00 & 277.00 & 263.00 & 247.00 & 212.00 \\
\hline & Chloride & 24 & 19.30 & 11.10 & 15.20 & 18.70 & 16.00 & 15.40 & 14.10 & 12.00 \\
\hline \multirow[t]{5}{*}{$3 \mathrm{E}-1$} & $\begin{array}{l}\text { Specific con- } \\
\text { ductance }\end{array}$ & 5 & $1,150.00$ & 630.00 & 910.00 & $1,110.00$ & 940.00 & 920.00 & 910.00 & 686.00 \\
\hline & $\mathrm{pH}$ & 5 & 8.69 & 8.31 & 8.47 & 8.65 & 8.51 & 8.49 & 8.35 & 8.32 \\
\hline & Alkalinity & 5 & 222.00 & 194.00 & 208.00 & 220.00 & 212.00 & 211.00 & 203.00 & 196.00 \\
\hline & $\begin{array}{l}\text { Total dissolved } \\
\text { solids }\end{array}$ & 4 & 628.00 & 556.00 & 585.00 & 622.00 & 601.00 & 577.00 & 561.00 & 557.00 \\
\hline & Calcium & 4 & 48.40 & 37.00 & 42.60 & 48.10 & 46.80 & 42.60 & 38.50 & 37.30 \\
\hline
\end{tabular}


Table 3. Summary statistics for uncensored water-quality physical properties and constituents at sampling sites on Lake Sakakawea, Audubon Lake, and McClusky Canal, central North Dakota, 1990-2003. —Continued

[Specific conductance in microsiemens per centimeter at 25 degrees Celsius; $\mathrm{pH}$ in standard units; other constituent concentrations in milligrams per liter]

\begin{tabular}{|c|c|c|c|c|c|c|c|c|c|c|}
\hline \multirow[b]{2}{*}{ Site } & \multirow{2}{*}{$\begin{array}{c}\text { Physical } \\
\text { property or } \\
\text { constituent }\end{array}$} & \multicolumn{4}{|c|}{ Descriptive statistics } & \multicolumn{5}{|c|}{$\begin{array}{l}\text { Percentage of samples in which values were } \\
\text { less than or equal to those shown }\end{array}$} \\
\hline & & $\begin{array}{c}\text { Sample } \\
\text { size }\end{array}$ & Maximum & Minimum & Mean & 95 & 75 & $\begin{array}{c}\text { (Median) } \\
50\end{array}$ & 25 & 5 \\
\hline \multirow[t]{5}{*}{$3 \mathrm{E}-1$} & Magnesium & 4 & 38.50 & 35.00 & 36.80 & 38.50 & 38.50 & 36.80 & 35.00 & 35.00 \\
\hline & Sodium & 4 & 134.00 & 109.00 & 123.00 & 133.00 & 128.00 & 125.00 & 120.00 & 111.00 \\
\hline & Potassium & 4 & 8.69 & 7.20 & 7.77 & 8.54 & 7.95 & 7.59 & 7.41 & 7.24 \\
\hline & Sulfate & 5 & 282.00 & 254.00 & 272.00 & 282.00 & 279.00 & 279.00 & 267.00 & 257.00 \\
\hline & Chloride & 5 & 16.40 & 14.80 & 15.60 & 16.40 & 16.20 & 15.60 & 15.10 & 14.80 \\
\hline \multirow[t]{10}{*}{$3 \mathrm{E}-2$} & $\begin{array}{l}\text { Specific con- } \\
\text { ductance }\end{array}$ & 16 & $1,160.00$ & 610.00 & 954.00 & $1,110.00$ & $1,060.00$ & 950.00 & 910.00 & 700.00 \\
\hline & $\mathrm{pH}$ & 16 & 8.78 & 8.29 & 8.44 & 8.71 & 8.47 & 8.41 & 8.34 & 8.30 \\
\hline & Alkalinity & 16 & 308.00 & 141.00 & 201.00 & 273.00 & 203.00 & 193.00 & 184.00 & 162.00 \\
\hline & $\begin{array}{l}\text { Total dissolved } \\
\text { solids }\end{array}$ & 16 & 884.00 & 374.00 & 608.00 & 794.00 & 685.00 & 595.00 & 538.00 & 459.00 \\
\hline & Calcium & 16 & 68.00 & 32.00 & 48.20 & 65.50 & 52.40 & 47.00 & 41.00 & 36.00 \\
\hline & Magnesium & 16 & 59.10 & 23.10 & 38.00 & 53.60 & 44.50 & 34.50 & 33.00 & 27.10 \\
\hline & Sodium & 16 & 171.00 & 62.30 & 108.00 & 145.00 & 114.00 & 112.00 & 92.40 & 74.80 \\
\hline & Potassium & 16 & 12.50 & 5.90 & 7.80 & 12.10 & 8.13 & 7.11 & 6.65 & 5.97 \\
\hline & Sulfate & 16 & 392.00 & 156.00 & 275.00 & 386.00 & 309.00 & 263.00 & 248.00 & 198.00 \\
\hline & Chloride & 16 & 20.50 & 9.88 & 14.90 & 19.20 & 16.40 & 14.90 & 12.60 & 11.10 \\
\hline \multirow[t]{10}{*}{$8 \mathrm{I}$} & $\begin{array}{l}\text { Specific con- } \\
\text { ductance }\end{array}$ & 31 & $1,610.00$ & 750.00 & $1,250.00$ & $1,590.00$ & $1,420.00$ & $1,270.00$ & $1,070.00$ & 945.00 \\
\hline & $\mathrm{pH}$ & 31 & 8.96 & 8.10 & 8.50 & 8.82 & 8.59 & 8.50 & 8.39 & 8.16 \\
\hline & Alkalinity & 33 & 291.00 & 183.00 & 231.00 & 266.00 & 238.00 & 225.00 & 220.00 & 216.00 \\
\hline & $\begin{array}{l}\text { Total dissolved } \\
\text { solids }\end{array}$ & 33 & $1,180.00$ & 613.00 & 852.00 & $1,120.00$ & 978.00 & 860.00 & 713.00 & 628.00 \\
\hline & Calcium & 33 & 93.30 & 40.00 & 60.00 & 80.30 & 68.70 & 59.00 & 49.50 & 40.40 \\
\hline & Magnesium & 33 & 99.70 & 43.00 & 63.30 & 88.40 & 74.70 & 61.10 & 47.00 & 44.00 \\
\hline & Sodium & 33 & 158.00 & 103.00 & 134.00 & 151.00 & 143.00 & 135.00 & 128.00 & 118.00 \\
\hline & Potassium & 33 & 17.60 & 7.60 & 12.00 & 17.10 & 13.70 & 11.50 & 9.10 & 8.40 \\
\hline & Sulfate & 33 & 669.00 & 277.00 & 435.00 & 635.00 & 529.00 & 422.00 & 323.00 & 297.00 \\
\hline & Chloride & 33 & 22.40 & 15.10 & 17.90 & 21.60 & 18.90 & 17.90 & 16.70 & 15.20 \\
\hline \multirow[t]{4}{*}{$8 \mathrm{H}$} & $\begin{array}{l}\text { Specific con- } \\
\text { ductance }\end{array}$ & 18 & $1,660.00$ & 780.00 & $1,200.00$ & $1,610.00$ & $1,270.00$ & $1,150.00$ & $1,080.00$ & 899.00 \\
\hline & $\mathrm{pH}$ & 18 & 8.93 & 8.06 & 8.49 & 8.88 & 8.57 & 8.48 & 8.41 & 8.09 \\
\hline & Alkalinity & 19 & 280.00 & 202.00 & 235.00 & 276.00 & 244.00 & 231.00 & 225.00 & 216.00 \\
\hline & $\begin{array}{l}\text { Total dissolved } \\
\text { solids }\end{array}$ & 19 & $1,180.00$ & 655.00 & 835.00 & $1,140.00$ & 923.00 & 766.00 & 721.00 & 671.00 \\
\hline
\end{tabular}


Table 3. Summary statistics for uncensored water-quality physical properties and constituents at sampling sites on Lake Sakakawea, Audubon Lake, and McClusky Canal, central North Dakota, 1990-2003. —Continued

[Specific conductance in microsiemens per centimeter at 25 degrees Celsius; $\mathrm{pH}$ in standard units; other constituent concentrations in milligrams per liter]

\begin{tabular}{|c|c|c|c|c|c|c|c|c|c|c|}
\hline Site & $\begin{array}{l}\text { Physical } \\
\text { property or } \\
\text { constituent }\end{array}$ & \multicolumn{4}{|c|}{ Descriptive statistics } & \multicolumn{5}{|c|}{$\begin{array}{l}\text { Percentage of samples in which values were } \\
\text { less than or equal to those shown }\end{array}$} \\
\hline \multirow[t]{5}{*}{$8 \mathrm{H}$} & Calcium & 19 & 94.00 & 38.00 & 58.50 & 87.30 & 67.50 & 53.90 & 45.80 & 40.70 \\
\hline & Magnesium & 19 & 87.40 & 43.60 & 59.10 & 85.10 & 67.30 & 53.90 & 50.10 & 44.00 \\
\hline & Potassium & 19 & 16.60 & 6.20 & 11.40 & 15.70 & 12.40 & 11.00 & 10.00 & 8.63 \\
\hline & Sulfate & 19 & 692.00 & 305.00 & 421.00 & 624.00 & 485.00 & 363.00 & 341.00 & 321.00 \\
\hline & Chloride & 19 & 21.20 & 15.50 & 18.00 & 19.60 & 18.70 & 17.90 & 17.30 & 16.20 \\
\hline \multirow{8}{*}{$1 \mathrm{E}-1$} & Alkalinity & 13 & 392.00 & 216.00 & 253.00 & 322.00 & 252.00 & 241.00 & 232.00 & 221.00 \\
\hline & $\begin{array}{l}\text { Total dissolved } \\
\text { solids }\end{array}$ & 13 & $1,270.00$ & 737.00 & 876.00 & $1,190.00$ & 943.00 & 794.00 & 763.00 & 739.00 \\
\hline & Calcium & 13 & 103.00 & 39.00 & 60.90 & 94.50 & 75.00 & 54.00 & 48.00 & 40.70 \\
\hline & Magnesium & 13 & 95.00 & 49.30 & 61.00 & 86.70 & 66.60 & 54.00 & 51.80 & 49.50 \\
\hline & Sodium & 13 & 163.00 & 129.00 & 144.00 & 161.00 & 153.00 & 143.00 & 136.00 & 130.00 \\
\hline & Potassium & 13 & 17.60 & 9.20 & 12.00 & 16.90 & 12.10 & 11.00 & 10.70 & 9.80 \\
\hline & Sulfate & 13 & 645.00 & 337.00 & 435.00 & 643.00 & 489.00 & 393.00 & 363.00 & 341.00 \\
\hline & Chloride & 13 & 20.10 & 15.80 & 18.40 & 19.60 & 19.10 & 18.50 & 18.00 & 16.60 \\
\hline \multirow{7}{*}{$1 \mathrm{E}-2$} & $\begin{array}{l}\text { Total dissolved } \\
\text { solids }\end{array}$ & 22 & $1,400.00$ & 767.00 & $1,130.00$ & $1,330.00$ & $1,270.00$ & $1,220.00$ & $1,030.00$ & 777.00 \\
\hline & Calcium & 22 & 110.00 & 40.00 & 82.20 & 105.00 & 96.80 & 86.40 & 73.60 & 50.70 \\
\hline & Magnesium & 22 & 115.00 & 54.00 & 86.60 & 107.00 & 102.00 & 91.70 & 76.00 & 56.10 \\
\hline & Sodium & 22 & 171.00 & 133.00 & 156.00 & 166.00 & 164.00 & 158.00 & 150.00 & 142.00 \\
\hline & Potassium & 22 & 21.30 & 11.50 & 16.70 & 21.30 & 19.60 & 16.90 & 14.10 & 11.60 \\
\hline & Sulfate & 22 & 833.00 & 393.00 & 641.00 & 806.00 & 748.00 & 708.00 & 570.00 & 407.00 \\
\hline & Chloride & 22 & 24.60 & 14.70 & 18.90 & 22.60 & 20.00 & 18.40 & 17.80 & 16.40 \\
\hline \multirow[t]{3}{*}{$3 \mathrm{G}-3$} & $\begin{array}{l}\text { Specific con- } \\
\text { ductance }\end{array}$ & 19 & $1,730.00$ & 880.00 & $1,280.00$ & $1,670.00$ & $1,400.00$ & $1,250.00$ & $1,150.00$ & $1,020.00$ \\
\hline & $\mathrm{pH}$ & 19 & 8.89 & 7.74 & 8.44 & 8.70 & 8.61 & 8.46 & 8.32 & 7.99 \\
\hline & Alkalinity & 19 & 299.00 & 220.00 & 249.00 & 299.00 & 256.00 & 250.00 & 236.00 & 221.00 \\
\hline
\end{tabular}


Table 3. Summary statistics for uncensored water-quality physical properties and constituents at sampling sites on Lake Sakakawea, Audubon Lake, and McClusky Canal, central North Dakota, 1990-2003. _ Continued

[Specific conductance in microsiemens per centimeter at 25 degrees Celsius; $\mathrm{pH}$ in standard units; other constituent concentrations in milligrams per liter]

\begin{tabular}{|c|c|c|c|c|c|c|c|c|c|c|}
\hline \multirow[b]{2}{*}{ Site } & \multirow{2}{*}{$\begin{array}{l}\text { Physical } \\
\text { property or } \\
\text { constituent }\end{array}$} & \multicolumn{4}{|c|}{ Descriptive statistics } & \multicolumn{5}{|c|}{$\begin{array}{l}\text { Percentage of samples in which values were } \\
\text { less than or equal to those shown }\end{array}$} \\
\hline & & $\begin{array}{l}\text { Sample } \\
\text { size }\end{array}$ & Maximum & Minimum & Mean & 95 & 75 & $\begin{array}{l}\text { (Median) } \\
\quad 50\end{array}$ & 25 & 5 \\
\hline \multirow[t]{7}{*}{$3 \mathrm{G}-3$} & $\begin{array}{l}\text { Total dissolved } \\
\text { solids }\end{array}$ & 19 & $1,270.00$ & 760.00 & 914.00 & $1,210.00$ & $1,020.00$ & 831.00 & 785.00 & 765.00 \\
\hline & Calcium & 20 & 119.00 & 41.00 & 65.00 & 111.00 & 77.00 & 54.90 & 51.60 & 41.90 \\
\hline & Magnesium & 20 & 93.10 & 49.00 & 64.70 & 92.40 & 70.70 & 59.40 & 56.20 & 51.70 \\
\hline & Sodium & 20 & 175.00 & 124.00 & 148.00 & 173.00 & 154.00 & 147.00 & 139.00 & 130.00 \\
\hline & Potassium & 20 & 17.60 & 10.10 & 12.90 & 17.20 & 13.70 & 12.40 & 11.40 & 10.50 \\
\hline & Sulfate & 20 & 746.00 & 362.00 & 463.00 & 661.00 & 537.00 & 408.00 & 384.00 & 370.00 \\
\hline & Chloride & 20 & 23.60 & 14.30 & 18.70 & 21.30 & 19.40 & 18.40 & 18.10 & 15.80 \\
\hline \multirow[t]{10}{*}{$3 \mathrm{G}-1$} & $\begin{array}{l}\text { Specific con- } \\
\text { ductance }\end{array}$ & 12 & $1,480.00$ & 920.00 & $1,240.00$ & $1,480.00$ & $1,330.00$ & $1,190.00$ & $1,180.00$ & $1,040.00$ \\
\hline & $\mathrm{pH}$ & 12 & 8.89 & 7.88 & 8.41 & 8.79 & 8.54 & 8.43 & 8.25 & 8.02 \\
\hline & Alkalinity & 12 & 305.00 & 221.00 & 255.00 & 295.00 & 269.00 & 250.00 & 243.00 & 224.00 \\
\hline & $\begin{array}{l}\text { Total dissolved } \\
\text { solids }\end{array}$ & 12 & $1,120.00$ & 581.00 & 884.00 & $1,110.00$ & 971.00 & 851.00 & 814.00 & 703.00 \\
\hline & Calcium & 12 & 139.00 & 41.00 & 69.40 & 114.00 & 75.00 & 62.90 & 53.40 & 44.90 \\
\hline & Magnesium & 12 & 77.90 & 42.90 & 61.60 & 76.40 & 68.80 & 59.00 & 55.80 & 48.60 \\
\hline & Sodium & 12 & 178.00 & 113.00 & 143.00 & 168.00 & 149.00 & 141.00 & 136.00 & 120.00 \\
\hline & Potassium & 12 & 14.40 & 9.35 & 12.40 & 14.20 & 13.20 & 12.70 & 11.70 & 10.10 \\
\hline & Sulfate & 12 & 602.00 & 284.00 & 447.00 & 595.00 & 486.00 & 429.00 & 403.00 & 338.00 \\
\hline & Chloride & 12 & 20.90 & 12.90 & 18.00 & 20.80 & 18.70 & 17.90 & 17.40 & 15.20 \\
\hline \multirow[t]{10}{*}{$3 \mathrm{G}-2$} & $\begin{array}{l}\text { Specific con- } \\
\text { ductance }\end{array}$ & 9 & $1,910.00$ & 830.00 & $1,420.00$ & $1,830.00$ & $1,640.00$ & $1,340.00$ & $1,280.00$ & 966.00 \\
\hline & $\mathrm{pH}$ & 9 & 8.62 & 7.83 & 8.29 & 8.56 & 8.43 & 8.42 & 8.10 & 7.87 \\
\hline & Alkalinity & 10 & 295.00 & 228.00 & 254.00 & 284.00 & 262.00 & 253.00 & 241.00 & 230.00 \\
\hline & $\begin{array}{l}\text { Total dissolved } \\
\text { solids }\end{array}$ & 10 & $1,370.00$ & 830.00 & $1,070.00$ & $1,330.00$ & $1,240.00$ & $1,060.00$ & 887.00 & 839.00 \\
\hline & Calcium & 10 & 150.00 & 42.00 & 88.00 & 137.00 & 115.00 & 82.30 & 63.00 & 45.40 \\
\hline & Magnesium & 10 & 106.00 & 53.90 & 76.90 & 101.00 & 89.80 & 76.40 & 61.50 & 56.20 \\
\hline & Sodium & 10 & 166.00 & 136.00 & 155.00 & 164.00 & 161.00 & 156.00 & 150.00 & 142.00 \\
\hline & Potassium & 10 & 20.40 & 11.90 & 14.80 & 18.90 & 16.70 & 14.00 & 12.60 & 12.00 \\
\hline & Sulfate & 10 & 763.00 & 400.00 & 561.00 & 747.00 & 700.00 & 553.00 & 422.00 & 405.00 \\
\hline & Chloride & 10 & 23.60 & 14.90 & 18.50 & 22.20 & 18.70 & 18.30 & 17.90 & 15.20 \\
\hline $3 \mathrm{H}-1$ & $\begin{array}{l}\text { Specific con- } \\
\text { ductance }\end{array}$ & 19 & $2,120.00$ & $1,170.00$ & $1,600.00$ & $2,090.00$ & $1,900.00$ & $1,490.00$ & $1,380.00$ & $1,200.00$ \\
\hline & $\mathrm{pH}$ & 19 & 8.45 & 7.39 & 8.17 & 8.38 & 8.30 & 8.21 & 8.11 & 7.89 \\
\hline
\end{tabular}


Table 3. Summary statistics for uncensored water-quality physical properties and constituents at sampling sites on Lake Sakakawea, Audubon Lake, and McClusky Canal, central North Dakota, 1990-2003. _Continued

[Specific conductance in microsiemens per centimeter at 25 degrees Celsius; $\mathrm{pH}$ in standard units; other constituent concentrations in milligrams per liter]

\begin{tabular}{|c|c|c|c|c|c|c|c|c|c|c|}
\hline Site & $\begin{array}{l}\text { Physical } \\
\text { property or } \\
\text { constituent }\end{array}$ & \multicolumn{4}{|c|}{ Descriptive statistics } & \multicolumn{5}{|c|}{$\begin{array}{l}\text { Percentage of samples in which values were } \\
\text { less than or equal to those shown }\end{array}$} \\
\hline \multirow[t]{6}{*}{$3 \mathrm{H}-1$} & Alkalinity & 20 & 347.00 & 239.00 & 275.00 & 327.00 & 287.00 & 274.00 & 253.00 & 244.00 \\
\hline & $\begin{array}{l}\text { Total dissolved } \\
\text { solids }\end{array}$ & 20 & $1,740.00$ & 870.00 & $1,200.00$ & $1,710.00$ & $1,440.00$ & $1,120.00$ & 992.00 & 873.00 \\
\hline & Calcium & 20 & 150.00 & 58.00 & 94.10 & 142.00 & 108.00 & 87.90 & 72.00 & 64.70 \\
\hline & Magnesium & 20 & 129.00 & 57.00 & 87.90 & 124.00 & 103.00 & 85.10 & 71.40 & 58.20 \\
\hline & Sodium & 20 & 222.00 & 134.00 & 171.00 & 220.00 & 189.00 & 166.00 & 156.00 & 135.00 \\
\hline & Potassium & 20 & 29.20 & 12.60 & 20.50 & 28.30 & 24.60 & 19.90 & 17.30 & 12.70 \\
\hline \multirow[t]{7}{*}{$3 \mathrm{H}-2$} & $\begin{array}{l}\text { Specific con- } \\
\text { ductance }\end{array}$ & 17 & $2,440.00$ & $1,460.00$ & $1,870.00$ & $2,410.00$ & $2,060.00$ & $1,850.00$ & $1,590.00$ & $1,520.00$ \\
\hline & $\mathrm{pH}$ & 17 & 8.70 & 8.08 & 8.34 & 8.56 & 8.48 & 8.30 & 8.23 & 8.18 \\
\hline & Alkalinity & 18 & 342.00 & 191.00 & 255.00 & 320.00 & 272.00 & 250.00 & 235.00 & 208.00 \\
\hline & $\begin{array}{l}\text { Total dissolved } \\
\text { solids }\end{array}$ & 18 & $1,790.00$ & $1,030.00$ & $1,390.00$ & $1,750.00$ & $1,580.00$ & $1,410.00$ & $1,140.00$ & $1,060.00$ \\
\hline & Calcium & 18 & 139.00 & 68.80 & 85.80 & 102.00 & 88.80 & 81.40 & 79.40 & 70.80 \\
\hline & Magnesium & 18 & 140.00 & 72.30 & 106.00 & 140.00 & 126.00 & 104.00 & 90.50 & 72.50 \\
\hline & Sodium & 18 & 281.00 & 143.00 & 212.00 & 265.00 & 243.00 & 212.00 & 180.00 & 144.00 \\
\hline \multirow{9}{*}{$3 I-1$} & $\mathrm{pH}$ & 23 & 8.78 & 7.57 & 8.46 & 8.71 & 8.66 & 8.50 & 8.36 & 8.13 \\
\hline & Alkalinity & 22 & 381.00 & 200.00 & 304.00 & 368.00 & 333.00 & 314.00 & 273.00 & 229.00 \\
\hline & $\begin{array}{l}\text { Total dissolved } \\
\text { solids }\end{array}$ & 22 & $2,240.00$ & 977.00 & $1,700.00$ & $2,110.00$ & $2,000.00$ & $1,770.00$ & $1,400.00$ & $1,210.00$ \\
\hline & Calcium & 23 & 106.00 & 53.00 & 75.90 & 89.70 & 85.40 & 80.00 & 65.40 & 57.40 \\
\hline & Magnesium & 23 & 178.00 & 73.90 & 135.00 & 175.00 & 155.00 & 133.00 & 114.00 & 96.80 \\
\hline & Sodium & 23 & 363.00 & 144.00 & 270.00 & 359.00 & 316.00 & 283.00 & 225.00 & 176.00 \\
\hline & Potassium & 23 & 48.50 & 15.40 & 30.80 & 47.40 & 34.80 & 28.60 & 24.60 & 21.40 \\
\hline & Sulfate & 22 & $1,330.00$ & 548.00 & 993.00 & $1,290.00$ & $1,220.00$ & $1,030.00$ & 796.00 & 655.00 \\
\hline & Chloride & 22 & 40.10 & 13.20 & 28.10 & 39.80 & 35.20 & 29.20 & 21.30 & 15.60 \\
\hline
\end{tabular}


Table 3. Summary statistics for uncensored water-quality physical properties and constituents at sampling sites on Lake Sakakawea, Audubon Lake, and McClusky Canal, central North Dakota, 1990-2003. —Continued

[Specific conductance in microsiemens per centimeter at 25 degrees Celsius; $\mathrm{pH}$ in standard units; other constituent concentrations in milligrams per liter]

\begin{tabular}{|c|c|c|c|c|c|c|c|c|c|c|}
\hline \multirow[b]{2}{*}{ Site } & \multirow{2}{*}{$\begin{array}{l}\text { Physical } \\
\text { property or } \\
\text { constituent }\end{array}$} & \multicolumn{4}{|c|}{ Descriptive statistics } & \multicolumn{5}{|c|}{$\begin{array}{l}\text { Percentage of samples in which values were } \\
\text { less than or equal to those shown }\end{array}$} \\
\hline & & $\begin{array}{c}\text { Sample } \\
\text { size }\end{array}$ & Maximum & Minimum & Mean & 95 & 75 & $\begin{array}{c}\text { (Median) } \\
50\end{array}$ & 25 & 5 \\
\hline \multirow[t]{10}{*}{$3 \mathrm{I}-2$} & $\begin{array}{l}\text { Specific con- } \\
\text { ductance }\end{array}$ & 12 & $3,300.00$ & $2,150.00$ & $2,620.00$ & $3,210.00$ & $2,730.00$ & $2,610.00$ & $2,420.00$ & $2,180.00$ \\
\hline & $\mathrm{pH}$ & 12 & 8.47 & 7.93 & 8.29 & 8.45 & 8.42 & 8.32 & 8.20 & 8.03 \\
\hline & Alkalinity & 13 & 482.00 & 281.00 & 373.00 & 474.00 & 419.00 & 354.00 & 332.00 & 302.00 \\
\hline & $\begin{array}{l}\text { Total dissolved } \\
\text { solids }\end{array}$ & 12 & $2,680.00$ & $1,430.00$ & $2,010.00$ & $2,580.00$ & $2,230.00$ & $1,920.00$ & $1,780.00$ & $1,550.00$ \\
\hline & Calcium & 13 & 101.00 & 71.00 & 81.70 & 98.60 & 85.80 & 80.00 & 75.00 & 71.10 \\
\hline & Magnesium & 13 & 214.00 & 120.00 & 160.00 & 206.00 & 174.00 & 158.00 & 135.00 & 125.00 \\
\hline & Sodium & 13 & 457.00 & 241.00 & 331.00 & 434.00 & 374.00 & 328.00 & 281.00 & 255.00 \\
\hline & Potassium & 13 & 67.30 & 28.40 & 41.30 & 58.40 & 47.40 & 38.40 & 33.50 & 29.70 \\
\hline & Sulfate & 12 & $1,530.00$ & 883.00 & $1,160.00$ & $1,470.00$ & $1,290.00$ & $1,110.00$ & $1,010.00$ & 897.00 \\
\hline & Chloride & 13 & 42.30 & 22.10 & 31.50 & 39.30 & 35.70 & 31.30 & 29.70 & 22.30 \\
\hline \multirow[t]{10}{*}{$3 \mathrm{~K}$} & $\begin{array}{l}\text { Specific con- } \\
\text { ductance }\end{array}$ & 26 & $7,190.00$ & $1,820.00$ & $2,660.00$ & $3,320.00$ & $2,670.00$ & $2,560.00$ & $2,250.00$ & $1,890.00$ \\
\hline & $\mathrm{pH}$ & 26 & 8.78 & 8.25 & 8.55 & 8.72 & 8.66 & 8.60 & 8.44 & 8.28 \\
\hline & Alkalinity & 27 & 560.00 & 279.00 & 357.00 & 481.00 & 365.00 & 341.00 & 316.00 & 294.00 \\
\hline & $\begin{array}{l}\text { Total dissolved } \\
\text { solids }\end{array}$ & 27 & $6,540.00$ & $1,250.00$ & $2,080.00$ & $2,880.00$ & $2,140.00$ & $1,860.00$ & $1,660.00$ & $1,370.00$ \\
\hline & Calcium & 27 & 116.00 & 68.40 & 79.60 & 97.70 & 82.00 & 76.00 & 73.70 & 69.60 \\
\hline & Magnesium & 27 & 523.00 & 101.00 & 165.00 & 229.00 & 168.00 & 149.00 & 132.00 & 104.00 \\
\hline & Sodium & 27 & $1,290.00$ & 187.00 & 342.00 & 485.00 & 338.00 & 297.00 & 266.00 & 219.00 \\
\hline & Potassium & 27 & 76.00 & 22.70 & 36.50 & 59.50 & 39.00 & 32.70 & 29.20 & 23.90 \\
\hline & Sulfate & 27 & $4,110.00$ & 677.00 & $1,210.00$ & $1,640.00$ & $1,270.00$ & $1,110.00$ & 929.00 & 745.00 \\
\hline & Chloride & 27 & 146.00 & 19.40 & 36.40 & 46.90 & 38.00 & 31.60 & 26.40 & 22.30 \\
\hline \multirow[t]{10}{*}{$3 \mathrm{~J}$} & $\begin{array}{l}\text { Specific con- } \\
\text { ductance }\end{array}$ & 20 & $17,300.00$ & $2,470.00$ & $8,870.00$ & $15,300.00$ & $10,400.00$ & $8,340.00$ & $6,460.00$ & $4,240.00$ \\
\hline & $\mathrm{pH}$ & 20 & 8.98 & 8.26 & 8.66 & 8.82 & 8.75 & 8.72 & 8.59 & 8.27 \\
\hline & Alkalinity & 21 & $1,380.00$ & 324.00 & 622.00 & $1,050.00$ & 696.00 & 618.00 & 406.00 & 325.00 \\
\hline & $\begin{array}{l}\text { Total dissolved } \\
\text { solids }\end{array}$ & 21 & $17,700.00$ & $1,870.00$ & $8,380.00$ & $17,000.00$ & $10,600.00$ & $7,220.00$ & $5,100.00$ & $3,530.00$ \\
\hline & Calcium & 21 & 223.00 & 79.00 & 111.00 & 149.00 & 119.00 & 106.00 & 94.00 & 81.00 \\
\hline & Magnesium & 21 & $1,320.00$ & 158.00 & 618.00 & $1,320.00$ & 754.00 & 589.00 & 425.00 & 187.00 \\
\hline & Sodium & 21 & $3,490.00$ & 274.00 & $1,650.00$ & $3,440.00$ & $1,910.00$ & $1,430.00$ & $1,130.00$ & 688.00 \\
\hline & Potassium & 21 & 248.00 & 34.00 & 112.00 & 222.00 & 127.00 & 107.00 & 76.70 & 45.40 \\
\hline & Sulfate & 21 & $11,500.00$ & $1,080.00$ & $5,430.00$ & $10,900.00$ & $6,930.00$ & $4,620.00$ & $3,570.00$ & $2,200.00$ \\
\hline & Chloride & 21 & 385.00 & 31.00 & 194.00 & 382.00 & 246.00 & 170.00 & 129.00 & 80.50 \\
\hline
\end{tabular}


Table 4. Summary statistics for censored water-quality constituent concentrations at sampling sites on Lake Sakakawea, Audubon Lake, and McClusky Canal, central North Dakota, 1990-2003.

[Concentration data in milligrams per liter]

Percentage of samples in which values were less than

Descriptive statistics or equal to those shown

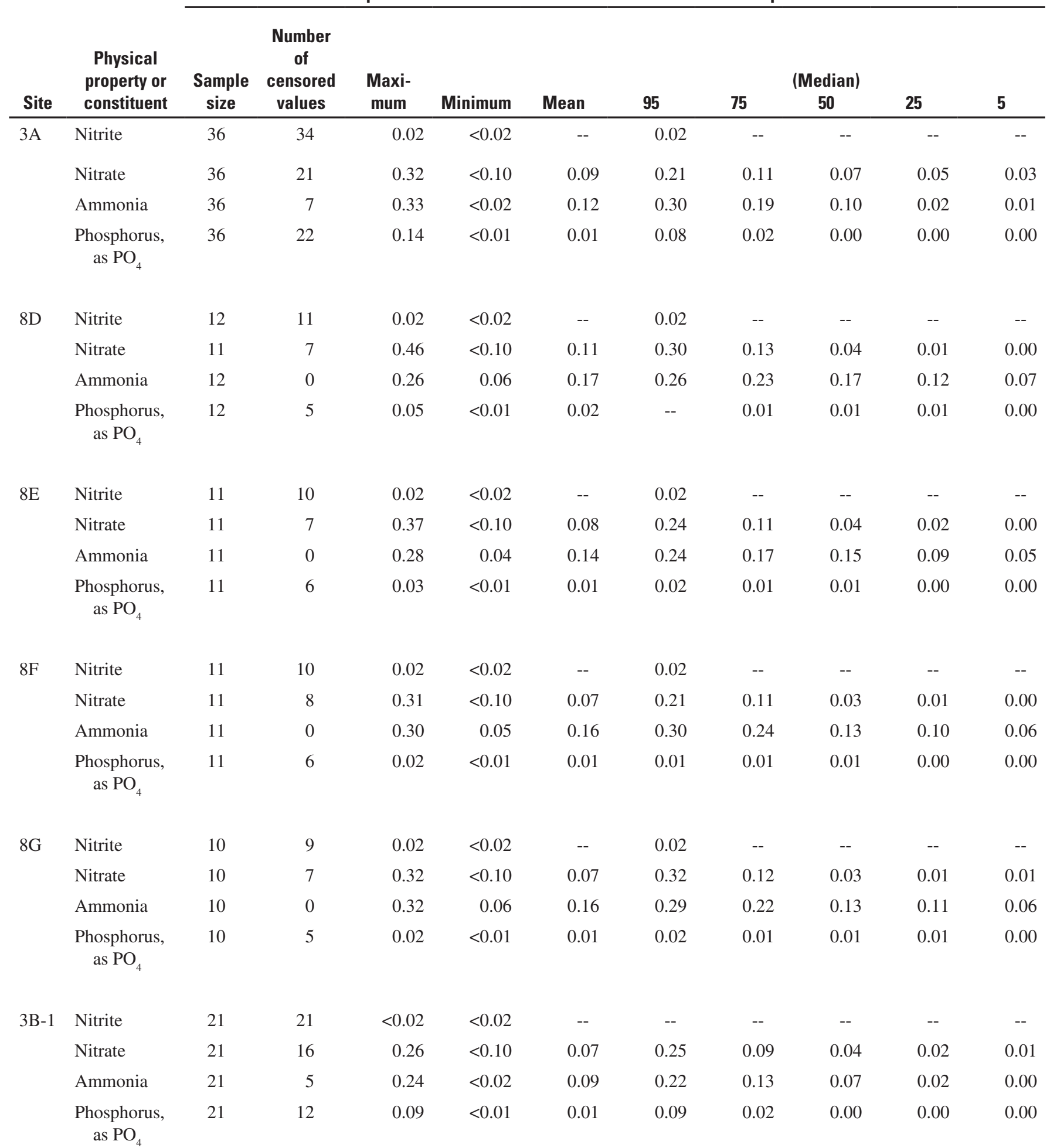


Table 4. Summary statistics for censored water-quality constituent concentrations at sampling sites on Lake Sakakawea, Audubon Lake, and McClusky Canal, central North Dakota, 1990-2003. _Continued

[Concentration data in milligrams per liter]

Percentage of samples in which values were less than or equal to those shown

\begin{tabular}{|c|c|c|c|c|c|c|c|c|c|c|c|}
\hline \multirow[b]{2}{*}{ Site } & \multirow[b]{2}{*}{$\begin{array}{l}\text { Physical } \\
\text { property or } \\
\text { constituent }\end{array}$} & \multicolumn{5}{|c|}{ Descriptive statistics } & \multicolumn{5}{|c|}{$\begin{array}{c}\text { Percentage of samples in which values were less than } \\
\text { or equal to those shown }\end{array}$} \\
\hline & & $\begin{array}{l}\text { Sample } \\
\text { size }\end{array}$ & $\begin{array}{c}\text { Number } \\
\text { of } \\
\text { censored } \\
\text { values }\end{array}$ & $\begin{array}{c}\text { Maxi- } \\
\text { mum }\end{array}$ & Minimum & Mean & 95 & 75 & $\begin{array}{l}\text { (Median) } \\
50\end{array}$ & 25 & 5 \\
\hline \multirow[t]{4}{*}{$3 \mathrm{~B}-2$} & Nitrite & 28 & 25 & 0.04 & $<0.02$ & -- & 0.02 & -- & -- & -- & -- \\
\hline & Nitrate & 27 & 19 & 0.62 & $<0.10$ & 0.07 & 0.47 & 0.10 & 0.03 & 0.01 & 0.00 \\
\hline & Ammonia & 28 & 6 & 0.73 & $<0.02$ & 0.17 & 0.49 & 0.21 & 0.11 & 0.02 & 0.00 \\
\hline & $\begin{array}{l}\text { Phosphorus, } \\
\text { as } \mathrm{PO}_{4}\end{array}$ & 28 & 18 & 0.10 & $<0.01$ & 0.01 & 0.08 & 0.01 & 0.00 & 0.00 & 0.00 \\
\hline \multirow[t]{4}{*}{$3 \mathrm{C}$} & Nitrite & 24 & 22 & 0.02 & $<0.02$ & -- & 0.02 & -- & -- & -- & -- \\
\hline & Nitrate & 24 & 17 & 2.80 & $<0.10$ & 0.17 & 2.20 & 0.12 & 0.01 & 0.00 & 0.00 \\
\hline & Ammonia & 24 & 0 & 0.36 & 0.03 & 0.20 & 0.33 & 0.27 & 0.19 & 0.14 & 0.06 \\
\hline & $\begin{array}{l}\text { Phosphorus, } \\
\text { as } \mathrm{PO}_{4}\end{array}$ & 24 & 12 & 0.15 & $<0.01$ & 0.02 & 0.13 & 0.02 & 0.01 & 0.00 & 0.00 \\
\hline \multirow[t]{4}{*}{$3 \mathrm{E}-1$} & Nitrite & 5 & 5 & $<0.02$ & $<0.02$ & -- & -- & -- & -- & -- & -- \\
\hline & Nitrate & 5 & 2 & 0.12 & $<0.10$ & 0.10 & -- & 0.10 & 0.10 & 0.06 & 0.01 \\
\hline & Ammonia & 5 & 0 & 0.25 & 0.13 & 0.19 & 0.24 & 0.21 & 0.21 & 0.14 & 0.13 \\
\hline & $\begin{array}{l}\text { Phosphorus, } \\
\text { as } \mathrm{PO}_{4}\end{array}$ & 5 & 3 & 0.01 & $<0.01$ & -- & 0.01 & 0.01 & -- & -- & -- \\
\hline \multirow[t]{4}{*}{$3 \mathrm{E}-2$} & Nitrite & 16 & 15 & 0.02 & $<0.02$ & -- & 0.02 & -- & -- & -- & -- \\
\hline & Nitrate & 16 & 11 & 0.26 & $<0.10$ & 0.08 & 0.23 & 0.12 & 0.06 & 0.03 & 0.01 \\
\hline & Ammonia & 16 & 0 & 0.40 & 0.04 & 0.17 & 0.36 & 0.25 & 0.13 & 0.10 & 0.06 \\
\hline & $\begin{array}{l}\text { Phosphorus, } \\
\text { as } \mathrm{PO}_{4}\end{array}$ & 16 & 8 & 0.03 & $<0.01$ & 0.01 & 0.03 & 0.01 & 0.01 & 0.00 & 0.00 \\
\hline \multirow[t]{4}{*}{$8 \mathrm{I}$} & Nitrite & 33 & 32 & 0.02 & $<0.02$ & -- & -- & -- & -- & -- & -- \\
\hline & Nitrate & 33 & 30 & 0.46 & $<0.10$ & -- & 0.12 & -- & -- & -- & -- \\
\hline & Ammonia & 33 & 5 & 0.44 & $<0.02$ & 0.15 & 0.39 & 0.20 & 0.12 & 0.05 & 0.01 \\
\hline & $\begin{array}{l}\text { Phosphorus, } \\
\text { as } \mathrm{PO}_{4}\end{array}$ & 33 & 19 & 0.11 & $<0.01$ & 0.01 & 0.08 & 0.02 & 0.00 & 0.00 & 0.00 \\
\hline \multirow[t]{4}{*}{$8 \mathrm{H}$} & Nitrite & 19 & 18 & 0.02 & $<0.02$ & -- & 0.02 & -- & -- & -- & -- \\
\hline & Nitrate & 19 & 18 & 0.40 & $<0.10$ & -- & 0.13 & -- & -- & -- & -- \\
\hline & Ammonia & 19 & 0 & 0.48 & 0.02 & 0.18 & 0.46 & 0.21 & 0.15 & 0.10 & 0.06 \\
\hline & $\begin{array}{l}\text { Phosphorus, } \\
\text { as } \mathrm{PO}_{4}\end{array}$ & 19 & 8 & 0.12 & $<0.01$ & 0.02 & -- & 0.02 & 0.01 & 0.01 & 0.00 \\
\hline
\end{tabular}


Table 4. Summary statistics for censored water-quality constituent concentrations at sampling sites on Lake Sakakawea, Audubon Lake, and McClusky Canal, central North Dakota, 1990-2003. _Continued

[Concentration data in milligrams per liter]

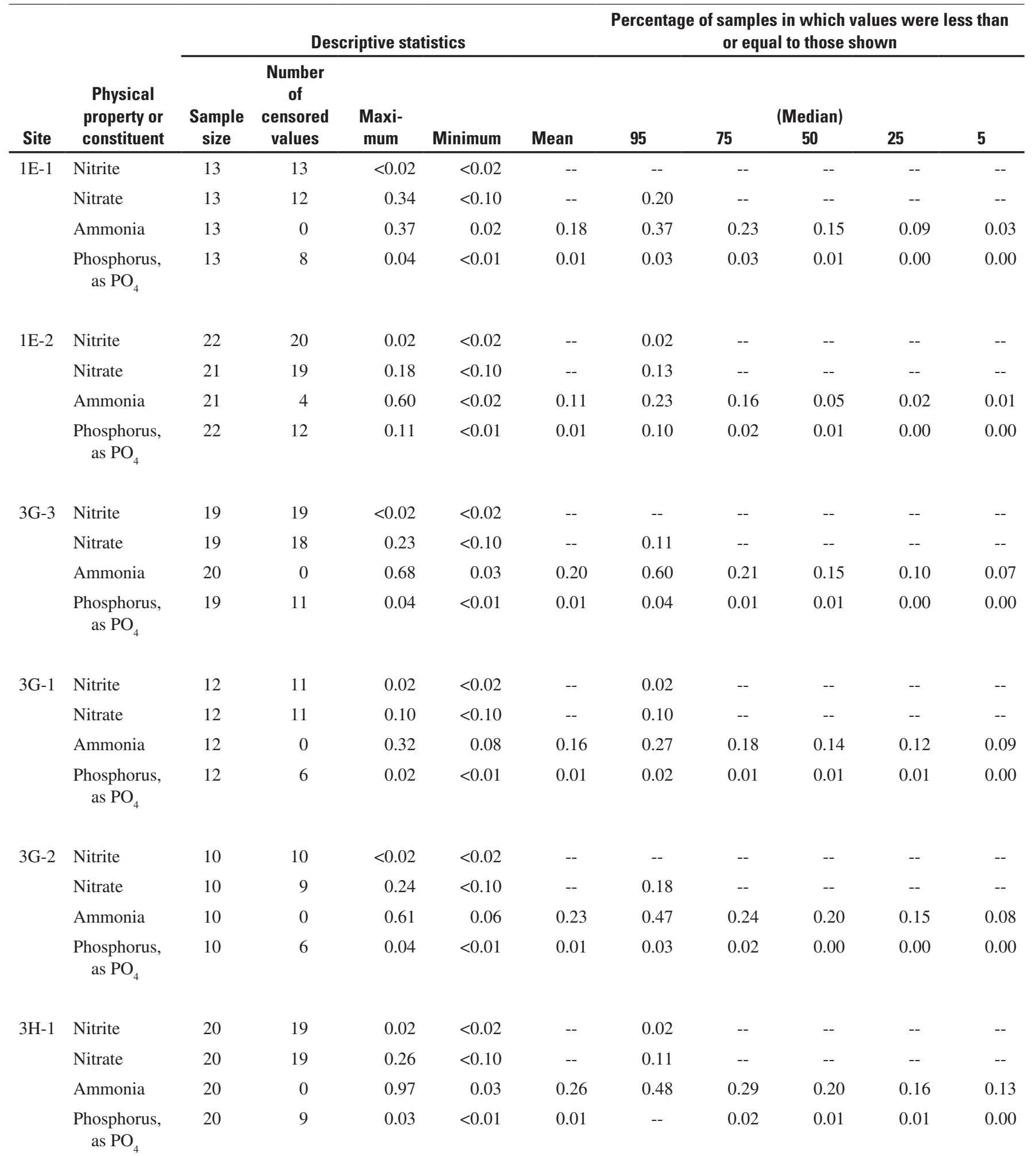


Table 4. Summary statistics for censored water-quality constituent concentrations at sampling sites on Lake Sakakawea, Audubon Lake, and McClusky Canal, central North Dakota, 1990-2003. _Continued

[Concentration data in milligrams per liter]

\begin{tabular}{|c|c|c|c|c|c|c|c|c|c|c|c|}
\hline \multirow[b]{2}{*}{ Site } & \multirow[b]{2}{*}{$\begin{array}{c}\text { Physical } \\
\text { property or } \\
\text { constituent }\end{array}$} & \multicolumn{5}{|c|}{ Descriptive statistics } & \multicolumn{5}{|c|}{$\begin{array}{c}\text { Percentage of samples in which values were less than } \\
\text { or equal to those shown }\end{array}$} \\
\hline & & $\begin{array}{l}\text { Sample } \\
\text { size }\end{array}$ & $\begin{array}{c}\text { Number } \\
\text { of } \\
\text { censored } \\
\text { values }\end{array}$ & $\begin{array}{c}\text { Maxi- } \\
\text { mum }\end{array}$ & Minimum & Mean & 95 & 75 & $\begin{array}{l}\text { (Median) } \\
50\end{array}$ & 25 & 5 \\
\hline \multirow[t]{3}{*}{$3 \mathrm{H}-2$} & Nitrite & 18 & 18 & $<0.02$ & $<0.02$ & -- & -- & -- & -- & -- & -- \\
\hline & Ammonia & 18 & 0 & 0.41 & 0.09 & 0.20 & 0.34 & 0.22 & 0.20 & 0.14 & 0.11 \\
\hline & $\begin{array}{l}\text { Phosphorus, } \\
\text { as } \mathrm{PO}_{4}\end{array}$ & 18 & 9 & 0.03 & $<0.01$ & 0.01 & 0.03 & 0.01 & 0.01 & 0.00 & 0.00 \\
\hline $3 \mathrm{I}-1$ & $\begin{array}{l}\text { Phosphorus, } \\
\text { as } \mathrm{PO}_{4}\end{array}$ & 23 & 9 & 0.06 & $<0.01$ & 0.02 & -- & 0.02 & 0.01 & 0.01 & 0.00 \\
\hline \multirow[t]{4}{*}{$3 \mathrm{I}-2$} & Nitrite & 13 & 12 & 0.02 & $<0.02$ & -- & 0.02 & -- & -- & -- & -- \\
\hline & Nitrate & 13 & 12 & 0.17 & $<0.10$ & -- & 0.13 & -- & -- & -- & -- \\
\hline & Ammonia & 13 & 0 & 0.71 & 0.08 & 0.42 & 0.70 & 0.65 & 0.43 & 0.20 & 0.12 \\
\hline & $\begin{array}{l}\text { Phosphorus, } \\
\text { as } \mathrm{PO}_{4}\end{array}$ & 13 & 4 & 0.07 & $<0.01$ & 0.03 & -- & 0.03 & 0.02 & 0.01 & 0.00 \\
\hline \multirow[t]{4}{*}{$3 \mathrm{~J}$} & Nitrite & 21 & 13 & 0.14 & $<0.02$ & 0.02 & 0.14 & 0.03 & 0.01 & 0.00 & 0.00 \\
\hline & Nitrate & 21 & 18 & 0.44 & $<0.10$ & -- & 0.18 & -- & -- & -- & -- \\
\hline & Ammonia & 21 & 0 & 4.74 & 0.12 & 1.14 & 2.65 & 1.69 & 0.76 & 0.38 & 0.21 \\
\hline & $\begin{array}{l}\text { Phosphorus, } \\
\text { as } \mathrm{PO}_{4}\end{array}$ & 21 & 1 & 0.80 & $<0.01$ & 0.13 & 0.69 & 0.10 & 0.05 & 0.03 & 0.01 \\
\hline
\end{tabular}


Table 7. Total dissolved-solids concentrations in samples from water-quality sampling sites located in section WS 2 of McClusky Canal, central North Dakota, 1990-2003.

[Concentration data in milligrams per liter; sites listed in downstream order]

\begin{tabular}{|c|c|c|c|c|c|c|c|c|c|}
\hline Date & $3 E-2$ & 81 & $8 \mathrm{H}$ & $1 E-1$ & 1E-2 & $3 G-3$ & $3 G-1$ & $3 G-2$ & $3 H-1$ \\
\hline $5 / 9 / 1990$ & 494 & & & & 767 & & 803 & & 971 \\
\hline $5 / 10 / 1990$ & & 631 & 727 & & & 768 & & & \\
\hline $8 / 30 / 1990$ & & 623 & 676 & & & 760 & & & \\
\hline 11/15/1990 & & & & & & & & & 1,110 \\
\hline 11/16/1990 & & & & 741 & & & 899 & & \\
\hline 11/19/1990 & & 613 & 655 & & & 766 & & & \\
\hline $5 / 22 / 1991$ & & & & & & & & & 889 \\
\hline $5 / 23 / 1991$ & & & & & & & & 850 & \\
\hline $5 / 24 / 1991$ & & 693 & 766 & & & 831 & & & \\
\hline 5/29/1991 & & & & & 839 & & & & \\
\hline $8 / 22 / 1991$ & & & & & & & & & 1,040 \\
\hline $8 / 26 / 1991$ & & 673 & 735 & 816 & & 800 & & 830 & \\
\hline $11 / 6 / 1991$ & & 713 & 699 & & 812 & 844 & 847 & & \\
\hline 8/12/1992 & & 712 & 729 & 748 & & 770 & 811 & & \\
\hline 8/13/1992 & 599 & & & & & & & & 999 \\
\hline 9/17/1992 & & & & & & & & 879 & 999 \\
\hline $9 / 18 / 1992$ & & & & & & 827 & & & \\
\hline 11/17/1992 & 602 & & & 784 & & & 965 & & \\
\hline 11/19/1992 & & & & & & & & & 1,140 \\
\hline $3 / 5 / 1993$ & 723 & 745 & 807 & 783 & & 874 & & 914 & \\
\hline 5/10/1993 & 504 & 650 & 730 & 763 & & 812 & 823 & & \\
\hline $5 / 11 / 1993$ & & & & & & & & & 873 \\
\hline 8/25/1993 & 574 & 714 & 673 & 737 & & & 856 & & \\
\hline
\end{tabular}


Table 7. Total dissolved-solids concentrations in samples from water-quality sampling sites located in section WS 2 of McClusky Canal, central North Dakota, 1990-2003. - Continued

[Concentration data in milligrams per liter; sites listed in downstream order]

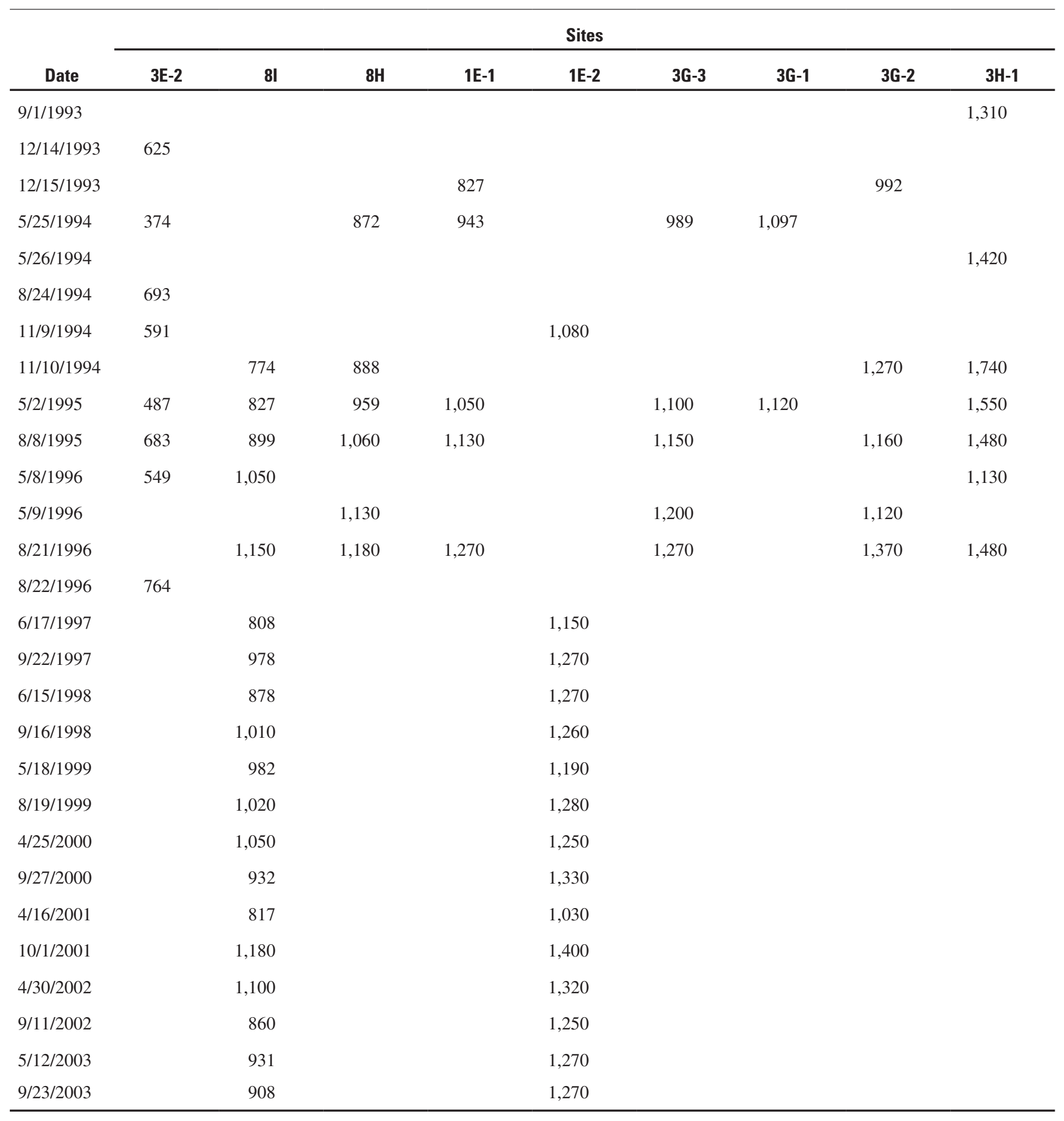


离

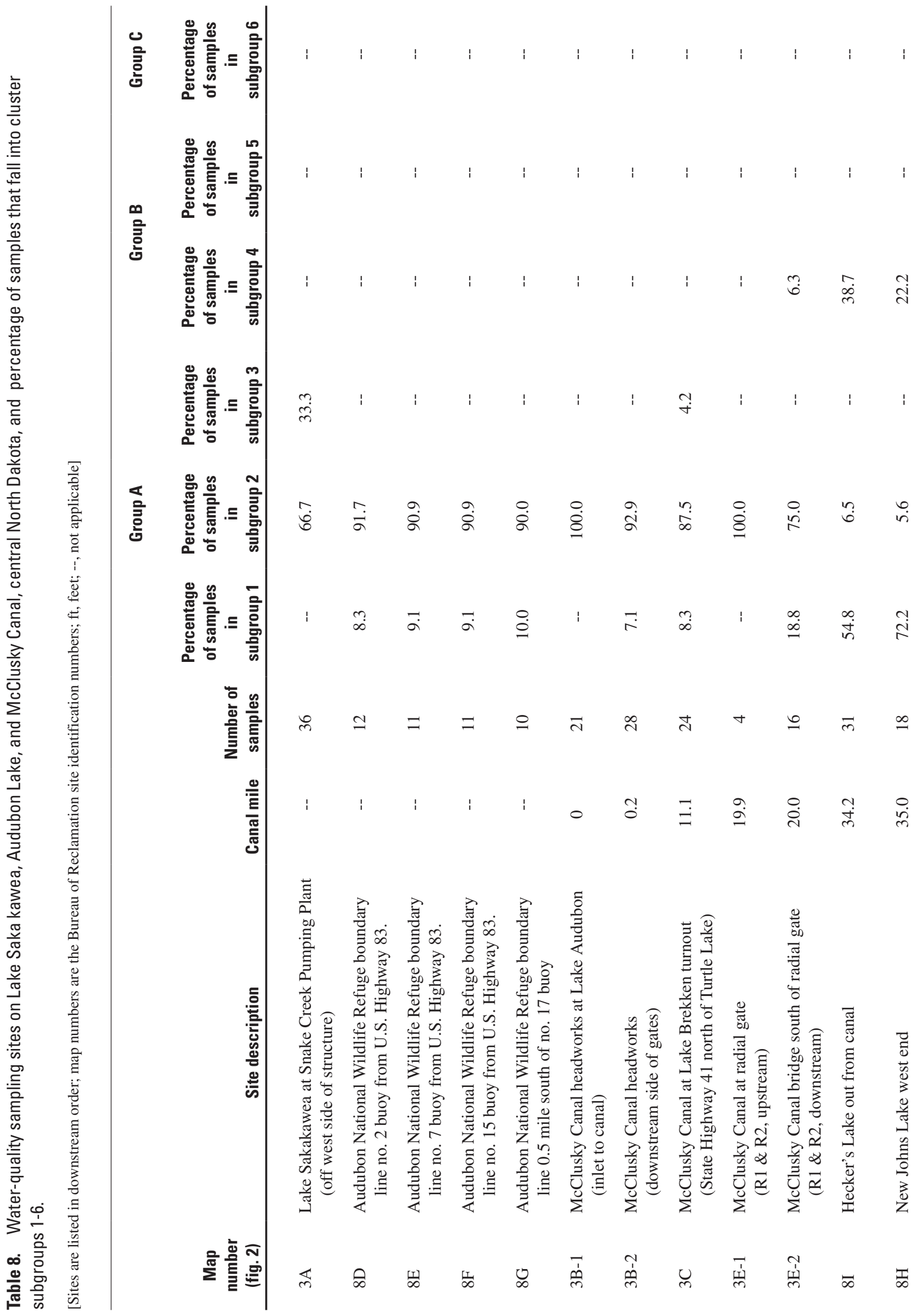




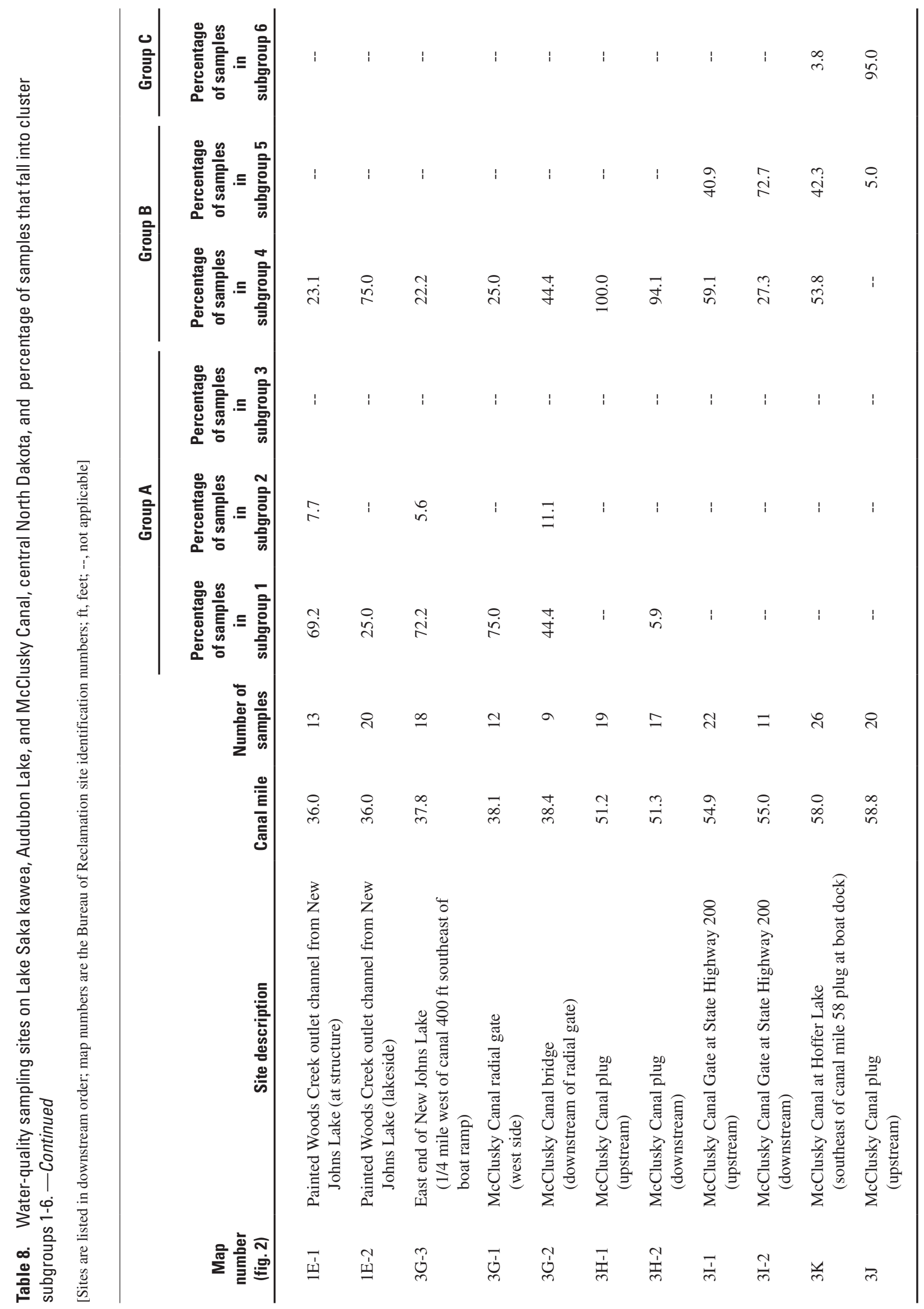





\section{蛋}

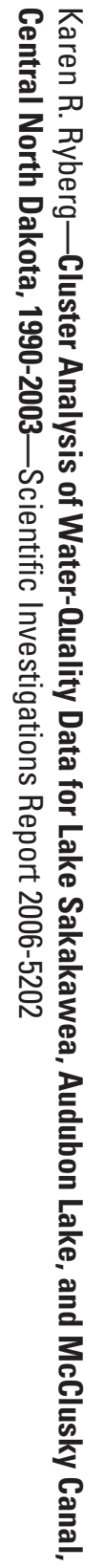

6 Printed on recycled paper 